\title{
Arşiv Belgelerine Dayanarak Narman Güvenlik Köyü Camii Üzerine Bir Değerlendirme
}

\section{An Evaluation of the Güvenlik Village Mosque in Narman Based on Archival Documents}

\author{
Burak Muhammet Gökler* (), Muhammed Emin Doğan*
}

\section{Öz}

Çalışmaya konu olan ve 1861 tarihinde Saliha Hanım tarafından yaptırılan Narman Güvenlik Köyü Camii’nin eski isminden hareketle (Gornes) arşiv belgeleri taraması yapılmış ve ulaşılan belgeler okunup değerlendirilmiştir. Kitabe tarihiyle de tutarlı olan arşiv belgesinden sonra yapının ahşap destekli olması nedeniyle giriş bölümünde Orta Asya ve Arap Yarımadası'ndan başlayan ve Osmanlı Devleti’ni içerisine alan kısa bir ahşap destekli cami gelişimi verilmiştir. Daha sonra yapının eskiden bağlı olduğu bölgeyle birlikte tarihçesi, mimari ve süsleme özellikleri irdelenip fotoğraflar ve çizimlerle desteklenmiştir. Erzurum'un Doğu Karadeniz'e komşu olan bir coğrafyada yer alması nedeniyle hem Doğu Karadeniz'deki hem de Erzurum'daki ahşap destekli camilerin karşılaştırılması gerçekleştirilmiştir. Ayrıca yapının kapı kanatlarından başlayan minber, mahfil, vaaz kürsüsü ve tavanında toplanan bezemeler bölgedeki eserlerle mukayese edilmiştir. Bu değerlendirme ve karşılaştırma sonucunda köyün, "Karadenizliler" tarafından kurulduğu ve caminin de "Karadenizli” ustalar tarafından inşa edildiği sonucuna ulaşılmıştır. Bununla birlikte harimi tezyin eden süslemelerin Karadeniz camilerinde görülen desen kurgusunu yansıttığı ortaya çıkartılmıştır.

Anahtar Kelimeler

Erzurum, Narman, Güvenlik Köyü Camii, Karadeniz

\section{Abstract}

In this study, archival materials were scanned and the obtained documents were read and evaluated based on the old name of the Güvenlik Village Mosque in Narman, which was built by Saliha Hanım in 1861 (Gornes). In the archival document, which corresponds to the history of the inscription, a short wooden-supported mosque development was presented in the entrance section, beginning with Central Asia and the Arabian Peninsula and ending the Ottoman Empire. Later, the historical, architectural, and ornamental features of the mosque were examined and supported by photographs and drawings. Since Erzurum is near the Eastern Black Sea, there has been a comparison of wooden-supported mosques in both the vicinity of the Eastern Black Sea and Erzurum. Furthermore, the structure's decorations have been compared with works in the region, beginning with the door wings and progressing to the pulpit, enclosure, preaching podium, and ceiling. Following this analysis and comparison, it was determined that the village was founded by "Karadenizliler" and that the mosque was built by "Black Sea" craftsmen. Additionally, it was discovered that the decorations of the worship area are similar to those observed in mosques along the Black Sea.

\section{Keywords}

Erzurum, Narman, Güvenlik Village Mosque, Black Sea

* Sorumlu Yazar: Burak Muhammet Gökler (Arş. Gör.) Atatürk Üniversitesi Edebiyat Fakültesi Sanat Tarihi Bölümü, Erzurum, İstanbul, Türkiye. E-posta: burak.gokler@atauni.edu.tr, ORCID: 0000-0002-5035-6756

** Muhammed Emin Doğan (Arş. Gör.) Atatürk Üniversitesi Edebiyat Fakültesi Sanat Tarihi Bölümü, Erzurum, İstanbul, Türkiye. E-posta: emin.dogan@atauni.edu.tr, ORCID: 0000-0002-6942-742X

Atıf: Gokler, Burak Muhammet ve Dogan Muhammed Emin. “Arşiv Belgelerine Dayanarak Narman Güvenlik Köyü Camii Üzerine Bir Değerlendirme." Art-Sanat, 16(2021): 181-219. https://doi.org/10.26650/artsanat.2021.16.0007 


\section{Extended Summary}

Trees have always been the most accessible natural resources for human throughout history. Without the use of many tools, trees have been sculpted and used to meet all the needs of humanity. Since the paleolithic period, wood has been the most important building material. It is the primary material for constructing buildings, tools, and weapons. With the transition to settled life, people began to use wood to build architectural structures. Communities that built huts out of wood later used trees in their architectural works. Thus, during the Hellenistic period communities in Greece, Rome, Egypt, China, Phoenicians, Frikians, Europe, and Mesopotamia profited from the benefits of trees.

The Turks have been using woods since their arrival in Central Asia. Wood was the main material used to construct the chambers of the tomb monuments known as kurgans in the Turkic States, which began with the Huns and continued with the Gokturks and Uighurs. Wooden pillars support the upper roofs of these rooms, which were built using the "çantı technique." Apart from that, the tents of the Turks, which were essential for their sheltering needs, were made of wood or supported by wooden pillars. Wooden carriers appear to have been preferred for the construction of houses and temples during the period of Uighurs who adopted a more stable lifestyle.

The first examples of mosque architectures (Masjid-i Nawebi), which emerged with the appearance of Islam, were built with wooden supports, and covered with tree leaves. As a result of the Turks' adoption of Islam, they used wood, which they know and use very well, in the construction of the mosque architecture. Some of the most exquisite examples are the Hive Masjid Friday, which was built during the time of the Karakhanids, and the Arus-el Felek mosque, which was built during the time of the Ghaznavids. The wooden tradition was not abandoned after the conquest of Anatolia. The Grand Mosque of Erzurum, one of the first principalities of Anatolia, was the first wooden-supported mosque. It was built during the reign of the Saltuks. According to Evliya Celebi, this mosque was built with 200 wooden pillars. The tradition of building wooden-supported mosques continued after the construction of the Grand Mosque of Erzurum during the Anatolian Seljuk and principality periods.

The tent tradition, which provided the most significant contributions to Turkish-Islamic architecture, was continued in the early days of the Ottoman Empire. Later, the first wooden-supported Samsa Cavus Mosque was built.

The Güvenlik Village Mosque in Narman District of Erzurum is a typical example of wooden-supported mosques that may be found during the Ottoman Empire period. The old name of the village is Gornes or Görnes. According to archival documents, the village is located within the borders of Oltu Village, which is connected to the Sanjak of Cildir. According to the Ottoman inscription on the marble on the entrance 
door, the mosque was built in 1861 (M.). The archival documents confirm the date. In addition to the date, important data have been found in the documents. Saliha Hanım was the first to build the Güvenlik Village Mosque, which falls into a special category because of the low number of mosques built by women in the region. The document clearly states that Abdullah bin Ali was the first imam of the mosque. Upon the death of Abdullah bin Ali, the duty of imam was passed to his sons. All of Abdullah bin Ali's sons are named, and descriptions of their appearance are provided, which is quite remarkable.

The last congregation place to the north of the mosque, which was built in a profoundly rectangular shape, is quite dilapidated. The residents of the village expressed that the west side of the last congregation place was used as a madrasa room. However, no such remains have been discovered.

The last congregation place can be accessed through a round-arched doorway. From this grass-covered area, the worship area can be accessed through an entryway with round arches and wooden door wings. The worship area within the mosque has no trace of ostentation. The dilapidated mihrab carved on the south wall of the worship area has a simple form. Unclear Muqarnas traces can be observed in the upper part of the mihrab.

The wooden pulpits to the east and west of the mihrab and sermon rostrum are distinguished by their authenticity. The women's hall, which extends to the north of the worship area, enlivens the interior with its unique decorations. The hall is flat and has a single balcony; it can be accessed through a stairway in the northwest side.

The ornamental features of the mosque are an important aspect that emphasizes its historical past and traces. The pulpit, mahfil (hall), sermon bench, and ceiling are all decked out with decorations that start from the door wings. The primary ornamental composition consists of pomegranate trees and matting on the door wings. This composition is surrounded by almond crossings and zigzags on the outside.

The pomegranate trees, which are called the fruit of Heaven, are embroiled as panels in the interior pulpit. Apart from the floral ornaments, almond, and zigzag motifs, which reflect the geometric design, were repeated. Additionally, a decorative pitcher motif on the pulpit also adds a different design language.

The mahfil (hall) and the beams that support it are another beautifully decorated area in the sanctuary. The bow ties in the architectural element, where the pomegranate trees and almond inserts are repeated, extend the idea of mosques in the Black Sea region.

The center of the wooden ceiling is the last area where the decoration can be observed. The center, which was largely destroyed, was decorated with rosette and geometric decorations as well as stamp motifs. 
When the architecture and decorative features of the mosque were evaluated, it was discovered that the mosque resembled mosques in the Eastern Black Sea region more than it resembles Erzurum structures. This suggests that the mosque was built by Black Sea craftsmen. 


\section{Giriş}

Tarihsel süreç içerisinde ağaç ve odun, insan yaşamında etkin bir rol almıştır. Paleolitik dönemden itibaren en önemli yapı malzemesi olan ağaç hem bina hem alet hem de silah yapımında kullanılmıştır ${ }^{1}$. Ahşabın mimaride kullanımıyla ilk olarak toplumların tarımsal düzeyde yerleşik hayata geçerek yapmış oldukları konutlarda karşılaşılmaktadır ${ }^{2}$. Mimarinin ilerlemesiyle birlikte ahşap, konut dışında diğer yapılarda da kendini göstermeye başlamıştır. Helenistik dönemde Yunanlılarda, Romalılarda, Fenikelilerde, Frikyalılarda, Mısır'da, Çin'de, Mezopotamya ve Avrupa'da kurulan pek çok medeniyet veya devlet, ağaç ve türevlerini kullanmıştır. Bu devlet ve medeniyetlerin mimarisi geliştikçe ve daha kaliteli malzemeye ulaştıkça ağaç, yerini diğer yapı elemanlarına bırakmıştır. Bunlar arasında Türklerin ahşaba olan ilgileri farklı bir konumdadır.

Türklerin ahşapla tanışık olmaları ortaya çıktıkları Orta Asya topraklarına kadar uzanmaktadır. MÖ 1500-MS 500 arasına tarihlenen Hun Devleti'nin ${ }^{3}$ var oluşunu ispatlayan kurganlar ve kurganlardan çıkan ahşaptan oyulmuş malzemeler, Türklerin ahşabı ne kadar iyi kullandıklarına işaret eden birer kanıttır ${ }^{4}$. Ancak ahşabın taşıyıcı gücünden faydalandıklarını gösteren önemli üç husus vardır: Bunlardan birincisi ölen kişilerin kurganlarının inşa edilmesi sürecinde bedenlerinin bekletilmesi için yapmış oldukları ahşaptan kulübelerdir ${ }^{5}$. İkincisi kurganlardır. Bir veya birden fazla odaya sahip olan kurgan (mezar) odalarının, zemini, duvarları ve üst örtüsü karaçam kütüklerinden " "çantı” tekniği ile meydana getirilmiş ayrıca üstten gelen baskıyı karşılamak içinde ahşap destekler atılmıştır ${ }^{7}$. Üçüncü husus da Orta Asya Kültürü’nün vazgeçilmezi olan çadırlardır. Yurt-Keregü adlarıyla da bilenen çadırlar ${ }^{8}$, büyüklük ve biçim açısından farklı tipleri ve adlandırmaları olmakla birlikte ana malzemesi ve taşı1cı sistemleri her zaman ahşap olmuştur. Hunlardan sonra 552-745 yıllarında tarih sahnesinde kalan Göktürkler (Kök-Türk) ${ }^{9}$, kurgan ve yurt tipi çadır yapımını sürdürmüştür ${ }^{10}$.

1 Robert L. Youngs, "History, Nature and Products of Wood", Forests And Forest Plants, Vol. II, (United Kingdom: EOLSS Publications, 2009), 131-140.

(http://www.eolss.net/sample-chapters/c10/e5-03-03-01.pdf)

2 Doğan Hasol, “Ahşap”, Eczacıbaşı Sanat Ansiklopedisi, c.1, (İstanbul: Yem Yayınevi, 1997), 33-34.

3 Alimcan Ziyai, "Orijinal Çin Kaynaklarına Göre Hun-Türk Tarihi I. Bölüm: Kudretli Büyük Hun Tanrıkutluğu (Türk Halkının Ataları Hunlar ve Hunların Ortaya Çıkışı)", Gazi Üniversitesi Eğitim Fakültesi Dergisi 30 (3), (2010), 895-912.

4 Yaşar Çoruhlu, Erken Devir Türk Sanatının ABC'si (İstanbul: Kabalcı Yayınevi, 1998), 73-74.

5 Haşim Karpuz, “İslam Öncesi Türk Sanatının İslami Döneme Etkisi”, Türkler Ansiklopedisi, C. 6, (Ankara: Yeni Türkiye Yayınlar, 2002), 48.

6 "Hun ve Göktürk Devrinde Kurgan ve Çadırlar", Türk Dünyası Kültür Atlası İslam Öncesi Dönem, haz. Yavuz Tiryaki (İstanbul: Türk Kültürüne Hizmet Vakfi, 1997), 57-58.

7 Yaşar Çoruhlu, Erken Devir Türk Sanatı (İstanbul: Kabalcı Yayınevi, 2007), 84-89.

8 Emel Esin, “Türk Kubbesi, Gök-Türklerden Selçuklulara Kadar”, Selçuklu Araştırmaları Dergisi III, Malazgirt Zaferi Özel Saylst (1971), 159.

9 Yaşar Çoruhlu, “Göktürk Sanatı”, Türkler Ansiklopedisi, c. 4 (Ankara: Yeni Türkiye Yayınları, 2002), 148.

10 Çoruhlu, Erken Devir Türk Sanatı, 158. 
Göktürkler, Hunlardan farklı olarak şehircilik anlayışını daha çok tercih etmişlerdir ${ }^{11}$. Özellikle Batı Göktürklerin yerleşik yaşamının en eski örneklerinden biri olan Ak-Beşim, VI. yüzyılda Orta Asya'nın ticaret ustası Soğdlarla' ${ }^{12}$, onlardan önce gelmiş olan Türk devletlerine başkentlik yapmıştır. Gerçekleştirilen arkeolojik kazı çalışmaları sonucunda VI. ve IX. yüzyıllar arasında dört farklı kültür katmanı olan kentte $^{13}$ ortaya çıkartılan iki Budist Tapınağı, Uygur tapınaklarıyla büyük benzerlik göstermektedir. Tapınağın avlu bölümünde yer alan koridorun üst örtüsünü çift sıra hâlindeki dörderli ahşap sütunlar taşımaktadır. Avludan sonra 18x10 m² ölçülerinde sekiz ahşap destekli ve kubbeli salona girilmektedir. Soğd halkıyla birçok şehirde iç içe yaşadığı bilinen Göktürklerin böyle bir tapınak yaptıklarını söylemek zor ${ }^{14}$ olsa da revaklı avlusu ve tepesi delikli kubbesi ile Türk izlerini yansıtmaktadır ${ }^{15}$. Akbeşim'den sonra Varahşa ${ }^{16}$ ve Pencikent'te de ahşap sütunların hatta heykelli ahşap taşıyıcıların varlığı ilgi uyandırmaktadır. Burada Türklerin varlığını kanıtlayan unsurlar, evlerin duvar resimlerindeki yoğ töreni ve Türk beyi ile kadının ata bindiği sahnelerdir ${ }^{17}$.

Göktürklerden sonra 744-842 yılları arasında Orta Asya (Orhon ve Selenga Nehrinden Aral Gölü kenarlarına kadar yayılan $)^{18}$ coğrafyasında hüküm süren Uygurların atlı arabaları oldukça meşhurdur. Ahşaptan yapılan bu araçlara savaş zamanlarında çok güvenilmekte, barışta ise bu arabaları ev olarak kullanmaktadırlar ${ }^{19}$. Atlı arabalar haricinde yurt tipi çadır geleneğini de devam ettirmişlerdir.

Yarı göçebe hayattan yerleşik düzene geçen Uygur Devleti, korunaklı ordu-kentler ve şehirler ${ }^{20}$ içerisinde tapınak, saray, köşk, manastır, türbe, kule, değirmen, buzhane ve sivil mimari örnekler (ev-konut) inşa etmişlerdir. Uygurlarda ahşabın mimariye katılımının en belirgin örneği evlerdir. Kara Hoço'da (Koço) tespit edilen evlerin beden duvarlarının toprak ve kerpiçten inşa edilerek aralarına ahşap destekler (direk) konulduğu bilinmektedir ${ }^{21}$.

11 Yılmaz Can, “Anadolu Öncesi Türk Kenti”, Türkler Ansiklopedisi, c. 3, (Ankara: Yeni Türkiye Yayınları, 2002), 259.

12 Soğdlarla bilgi için bk. Ahmet Taşağıl, "Soğd", TDV İslam Ansiklopedisi, c. 37, (İstanbul: Türkiye Diyanet Vakfi Yayınları, 2009), 348-349; Süer Eker, "Orta Asya'nın Gizemli Halkı: Soğdlular Soğd ve Soğdca", Türkbilig 24 (2012), 77-92.

13 Can, “Anadolu Öncesi Türk Kenti”, 261.

14 Çoruhlu, Erken Devir Türk Sanatı, 155-157; Mustafa Cezar, Anadolu Öncesi Türklerde Şehir ve Mimarllk, (İstanbul: Türkiye İș Bankası Kültür Yayınları, 1977), 34.

15 Cezar, Anadolu Öncesi Türklerde Şehir ve Mimarllk, 35.

16 Gözde Sazak, "Varahşa Sarayı Duvar Resimleri”, Tarih Dergisi 57 (2013), 1-23.

17 Cezar, Anadolu Öncesi Türklerde Şehir ve Mimarlı, 259.

18 Bahaddin Ögel, Türk Kültür Tarihi (Ankara: Türk Tarih Kurumu, 1984), 348.

19 Özkan İzgi, Kutluk Bilge Kül Kağan-Böğ̈̈ Kağan ve Uygurlar (Ankara: Kültür ve Turizm Bakanlığı Yayınları, 1986), 9-18.

20 Faruk Sümer, Eski Türklerde Şehircilik, (Ankara: Türk Dünyası Araştırmaları Vakfı Yayını, 1984), 27-49.

21 Aihemaiti Aibai, "Uygur Geleneksel Konut Mimarisinin Ekolojik Sürdürülebilirlik Bağlamında İncelenmesi: Kaşgar Tarihi Şehri Örneği”, (Yüksek Lisans Tezi, Mimar Sinan Güzel Sanatlar Üniversitesi, 2016), 27-29. 
Türk-İslam devletlerinden önce Arap Yarımadası'nda ahşap, yine ev olarak isimlendirilen çadırlarda kendini göstermektedir ${ }^{22}$. İslamiyet'in gelmesiyle birlikte bölgede ahşap kullanma geleneği devam etmiş ve cami mimarisine de yansımıştır. Cami mimarisinde ahşap malzemenin kullanımı ilk olarak Hz. Muhammed ile başlatılabilir. 622'de inşa edilen Mescid-i Nebevî ahşap desteğin kullanıldığı ilk ibadet yapısı olarak karşımıza çıkmaktadır ${ }^{23}$. Yine bu dönemde yapılan Kubâ Mescidi’nde de ahşap destekler tercih edilmiştir ${ }^{24}$. İslam mimarisine önemli katkılar sunan Emevilerin günümüze ulaşabilmiş ahşap destekli bir yapısı bulunmamaktadır. Ancak İran'ın Cürcan bölgesinde 26 cami inşa ettikleri ve çoğunluğunun ahşap destekli olduğu kaynaklarda geçmektedir $^{25}$. Abbasiler döneminde ise Nasır-i Hüsrev'inde bahsettiği ve bugün İsfahan Mescid-i Cuma〉sının yerinde olması gereken bir caminin ulu cami plan tipinde ahşap destekli olarak yapıldı̆̆ 1 ifade edilmektedir ${ }^{26}$.

Buhara ve çevresinde hüküm süren Sâmânîler pek çok yapı tipinde eserler ortaya koymuş olsalar da bunların birçoğu günümüze ulaşamamıştır. Ancak kaynaklarda geçen bilgilerden hareketle özellikle cami minarelerini ahşaptan inşa ettikleri bilinmektedir ${ }^{27}$. Bu sebeple camilerinde de ahşap desteği büyük ölçüde kullanmış olmaları muhtemeldir.

Ahşap destek konusunda en iyi örnekler Karahanlılar döneminde (840-1212) verilmiştir. Karahanlı hükümdarı Arslan Han, Buhara'da ahşap destekli bir ulu cami yapılmasını emretmiş ancak yapı sonradan yıkılmıştır ${ }^{28}$. Bu ilk eser dışında günümüze kadar varlığını sürdürmüş ahşap destekli en önemli yap1 10-11. yüzyıla tarihlendirilen Hive Ulu Camii'dir. 17 sahından meydana gelen eserin üst örtüsü 213 ahşap sütun tarafından taşınmaktadır. Bu taşıyıcıların 211'i çeşitli onarımlarda yenilenmiş veya ilave edilmiştir ${ }^{29}$. Gazneliler zamanında (963-1186) ${ }^{30}$ ahşap destekleriyle ön plana çıkan Arûs-i Felek Camii (10. yy) Hindistan'dan getirilen ağaçlar ile yapılmıştır ${ }^{31}$.

22 Nebi Bozkurt, "Çadır”, TDV İslam Ansiklopedisi, c. 8, (İstanbul: Türkiye Diyanet Vakfı Yayınları, 1993), 158-162.

23 Nebi Bozkurt ve Mustafa Sabri Küçükaşçı, "Mescid-i Nebevî”, TDV İslam Ansiklopedisi, c. 29, (Ankara: Türkiye Diyanet Vakfı Yayınları, 2004), 281-290.

24 Hüseyin Algül, "Mescid-i Kubâ", TDV İslam Ansiklopedisi, c. 29, (Ankara: Türkiye Diyanet Vakfı Yayınları, 2004), 279-280.

25 Semavi Eyice, "Cami, Mimarlık Tarihi" TDV İslam Ansiklopedisi, c. 7, (İstanbul: Türkiye Diyanet Vakfi Yayınlar1, 1993), 59, 62.

26 Büyük Selçuklu Mirası, c.2, (İstanbul: Türkiye Cumhuriyeti Cumhurbaşkanlığı, 2013), 12.

27 Muhlisahon Rustamova, "Karahanlı Devri Mimarisi ve Bezemeleri” (Doktora Tezi, Marmara Üniversitesi, 2019), 114-115, 125.

28 Rustamova, "Karahanlı Devri Mimarisi ve Bezemeleri", 125.

29 Boris Denike, "Batı Türkistan'da Ahşap Oymalı Birkaç Abide", çev: Osman Uysal, Vakıflar Dergisi XX, (1988), 29-38; "Juma Masjid (Xiva)", Özbekistan Milli Ansiklopedisi, c.1, (Taşkent: Devlet Bilimsel Yay1nevi, 2000), 404.

30 Erdoğan Merçil, "Gazneliler”, TDV İslam Ansiklopedisi, c. 13, (İstanbul, Türkiye Diyanet Vakfı Yayınları, 1996), 480-484.

31 Yllmaz Büktel, Türk Sanat Tarihi (Orta Asya'dan Anadolu'ya Türk Mimarisi), (Edirne: 1999), 15. 
Genellikle tuğla malzemeyi tercih ettiği bilinen Büyük Selçuklu Devleti döneminde de ahşap destekli camiler ile karşılaşılmaktadır. 1128 tarihinde inşa edilen Karug Camii'nde (Karukh) ${ }^{32}$ ahşap, taş ve tuğla malzeme kullanıldı̆̆ 1 için dönemin diğer yapılarından ayrılan caminin ahşap kısımlarının orijinal olduğu düşünülmekte ${ }^{33}, \mathrm{Bu}-$ hara ve Hive çevresindeki camilerle benzerlik göstermektedir. Bunun dişında Abyaneh (1084) ${ }^{34}$ ve Bestam Camii'de $(1120)^{35}$ ahşap destekli eserlerin nadir örnekleri arasindadir.

Ahşap desteğin Anadolu'ya gelişini ise Orta Asya ile birlikte cami mimarisinin ortaya çıktığı Arap Yarımadası'na bağlamak doğru olacaktır. Türklerin Orta Asya'dan gelen ahşap bilgisi Arap Yarmadası'nda ortaya çıkan ahşap destekli cami mimarisinin gelişimine büyük ölçüde katkı sağlamıştır. Bu sebeple bu tip yapıları sadece Orta Asya'ya veya doğrudan Arap Yarımadası'na bağlamak doğru bir yaklaşım olmayacaktır.

Anadolu'da ahşap destekli olarak inşa edilen ilk yapı ise Erzurum Ulu Camii'dir. 1174-1189'da Saltuklular tarafından yaptırılan eser $^{36}$ ile ilgili Evliya Çelebi, iki yüz adet çam direklerin varlığından bahsetmektedir ${ }^{37}$. Kargir hâlini ise 17. yüzyıldan sonra almıştır ${ }^{38}$. İkinci ahşap destekli cami, İspir İlçesi'nde bulunan 1202-1220 ${ }^{39}$ yılları arasına tarihlenen Tuğrul Şah Camii'dir.

İlk beyliklerden sonra Anadolu Selçuklu ve İkinci Beylikler döneminde pek çok ahşap destekli eserin inşa edildiği görülmektedir. Bu camiler arasındaki en erken tarihli örneklerden birisi Konya'daki Sahip Ata Camii'dir. 1258 tarihli cami, 1871'de ahşap destekli ve mihraba dikey beş sahınlı olarak yeniden düzenlenmiştir. 1964'te caminin özgün durumunu ortaya çıkartmak için gerçekleştirilen kazı ve sondaj çalışmalarında ise eserin ahşap sütunlarla meydana getirilmiş mihraba dikey yedi sahınlı bir şema sergilediği ve mihrap önü kubbeli olduğu vurgulanmıştır ${ }^{40}$. Bir diğer eser 1272 yılında

32 Warwick Ball, Archaeological Gazetteer of Afghanistan, Tome I (Paris, Éditions Recherche sur les Civilisations, 1982), 149.

33 Büyük Selçuklu Mirası, c. I (İstanbul: Türkiye Cumhuriyeti Cumhurbaşkanlığı, 2013), 90.

34 Büyük Selçuklu Mirası, c.1, 236-237,

35 Erişim 5 Şubat 2021, http://www.iranicaonline.org/articles/bestam-3\#prettyPhoto[content]/0/

36 İbrahim Hakk1 Konyalı, Abideleri ve Kitabeleri İle Erzurum, (İstanbul: Ercan Matbaas1, 1960), 267, Haluk Karamağralı, "Erzurum Ulu Camii” Yıllık Araştırmaları Dergisi III (1981), 137-178; Haldun Özkan, Saltuklu Mimarisi (Erzurum: Zafer Medya Grup, 2016), 98.

37 Yücel Dağl1 ve Seyit Ali Kahraman, Günümüz Türkçesiyle Evliya Çelebi Seyahatnamesi: Bursa-Bolu-Trabzon-Erzurum-Azerbaycan-Kafkasya-Kırım-Girit, c. 2, 1. Kitap (İstanbul: Yap1 Kredi Yayınlar1 2008), 240.

38 Konyalı, Abideleri ve Kitabeleri Ile Erzurum, 267.

39 Faruk Sümer, “Tuğrul Şah”, TDV İslam Ansiklopedisi, c. 41 (İstanbul: Türkiye Diyanet Vakfı Yayınları, 2012), 346-347.

40 Sevgi Parlak, "Sâhib Ata Külliyesi”, TDV İslam Ansiklopedisi, c. 35, (İstanbul: Türkiye Diyanet Vakfi Yayınları, 2008), 516-518, Haluk Karamağralı, "Sâhib Atâ Câmii'nin Restitüyonu Hakkında Bir Deneme”, Rölöve ve Restorasyon Dergisi, 3 (1985), 49-75. 
inşa edilen ${ }^{41}$ ve çeşitli onarımlarla günümüze kadar ulaşan Afyonkarahisar'daki Ulu Camii'dir. Cami, mukarnas başlıklı ahşap sütunlarla mihraba dikey dokuz sahından müteşekkildir ${ }^{42}$. Altmış yedi adet ahşap sütunu ile ön plana çıkan Eskişehir Sivrihisar Ulu Camii (1274-75) ${ }^{43}$, mihraba paralel beş sahınlıdır ${ }^{44}$. Ahşap destekli eserlerin belki de en seçkin yapıları arasında Beyşehir'deki Eşrefoğlu ve Kastamonu'daki Mahmut Bey Camii yer almaktadır. Çinileriyle de ön plana çıkan 1297 tarihli Eşrefoğlu Camii, mukarnas başlıklı altı sıra hâlindeki ahşap direklerle mihraba dikey yedi sahına ayrılmıştır ${ }^{45}$. Kastamonu Mahmut Bey Camii (1366) ise profilli yastıklara oturan ahşap sütunları ile dikkat çekmektedir ${ }^{46}$.

Bir beylik olarak ortaya çıkan Osmanlı Devleti de Orta Asya'dan gelen çadır geleneğinden vazgeçmemiştir. Bununla birlikte Anadolu'nun her yerinde karşımıza çıkacak olan ve daha kolay inşa edilebilen ahşap destekli camiler meydana getirmiştir. Bunlardan birincisi, Osman Gazi döneminde yapılan (1299-1324) ${ }^{47}$ Samsa Çavuş Camii'dir. Moloz taş örgülü ve kare planlı yapının iç bölümüne konulan ahşap direk üst örtüyü taşımaktadır. Bu yapı dışında imparatorluğun sonuna kadar fethedilmiş her bir toprağa bu tipte pek çok cami inşa edilmiştir. Özellikle Batılılaşma dönemiyle birlikte bu sayı daha da artmıştır. Başkente uzak yerel beldelerde ihtiyaca binaen yörenin ileri gelenleri veya yöre halkı tarafından ahşap destekli veya tavanlı olarak sayısız cami bina edilmiştir. Bu husus, Doğu Anadolu ve Kuzeydoğu Anadolu Bölgesi'nde daha net bir şekilde görülmektedir ki konunun temeli oluşturan cami de bir köy yapısı olarak bu duruma örnek teşkil etmektedir.

41 Hasan Usame Aydın, Tarihi Ahşap Camiler (İstanbul: Kutlu Yayınevi, 2017), 84-96.

42 Muhammet Arslan, "Anadolu'da Selçuklu Çağı Cami ve Mescit Mimarisi”" (Doktora Tezi, Atatürk Üniversitesi, 2017), 56.

43 Erol Altınsapan, "Sivrihisar"da Selçuklu Eserleri”, Eskişehir 1. Selçuklu Eserleri Semineri Bildirileri, (Eskişehir: Eskişehir Valiliği Yayınları, 1990), 24.

44 Arslan, Anadolu'da Selçuklu Çă̆l Cami ve Mescit Mimarisi, 527

45 Doğan Yavaş, "Eşrefoğlu Camii”, TDV İslam Ansiklopedisi, c. 11, (İstanbul: Türkiye Diyanet Vakfı Yayınları, 1995), 479-480.

46 Mahmut Akok, “Kastamonu’nun Kasaba Köyündeki Candaroğlu Mahmut Bey Camii” Belleten X/38 (1946), 294.

47 Osmanlı Ansiklopedisi, c.12 (Ankara: Yeni Türkiye Yayınları, 1999), 17-21. 


\section{Güvenlik Köyü Camii}

Cami, Erzurum ilinin kuzeyindeki Narman ilçesine bağlı eski adı "Go(ö)rnes” olarak geçen Güvenlik Köyü’nde yer almaktadır (G.1, G.2, G.3). İncelenen vesikalarda bölge, Çıldır Sancağı'ndaki Oltu Kazası mülhakatından Tavusger Kazası'na tâbi Görnes Karyesi olarak geçmektedir. Ayrıca yöre halkı yapılan görüşmelerde, köyün "Karadenizliler" tarafından kurulduğu dile getirilmiştir.
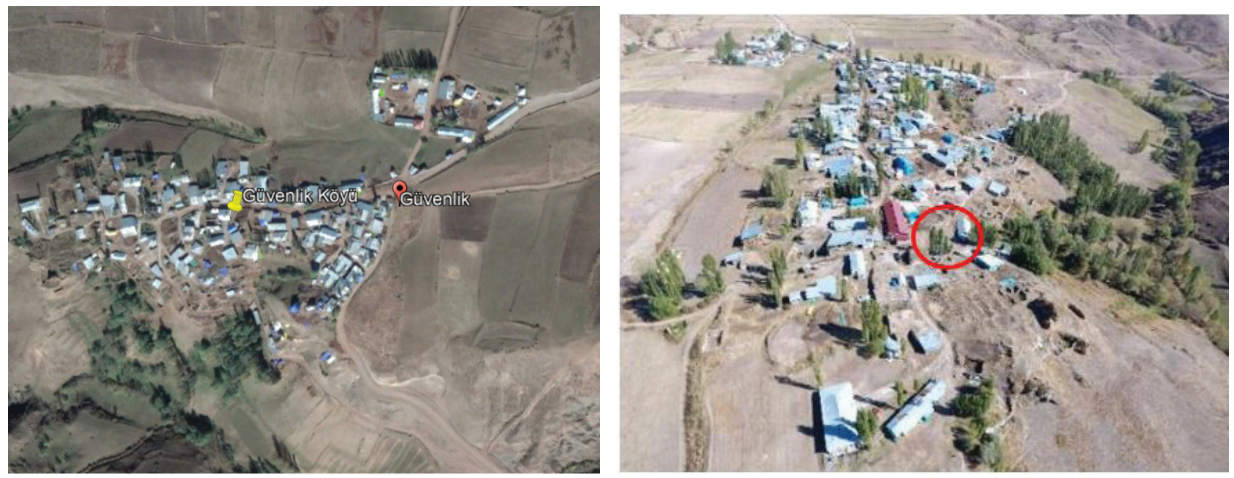

G. 1: Güvenlik Köyü (Google Earth)

G. 2: Köyün Hava Fotoğrafı ve Caminin Konumu (Gökler, 2020)

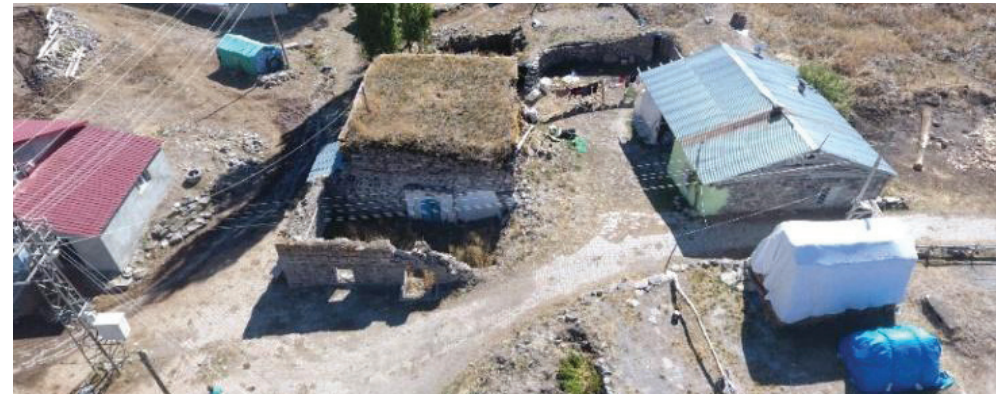

G. 3: Caminin Genel Görüntüsü (Gökler, 2020)

Yapının harim giriş kapısı üzerinde mermere işlenen altı satırlık sülüs hatlı Arap harfli kitabeye göre cami, H 1278/M 1861 yılında inşa edilmiştir (G. 4). 


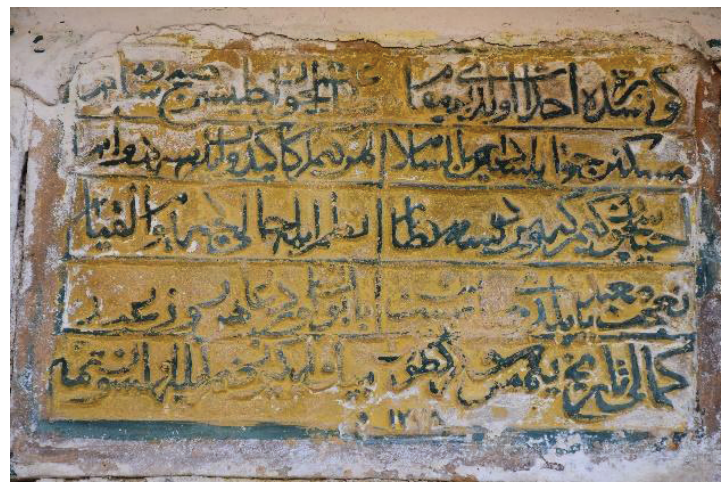

G. 4: Caminin Kitabesi (Gökler, 2020)

\section{Kitabe metni:}

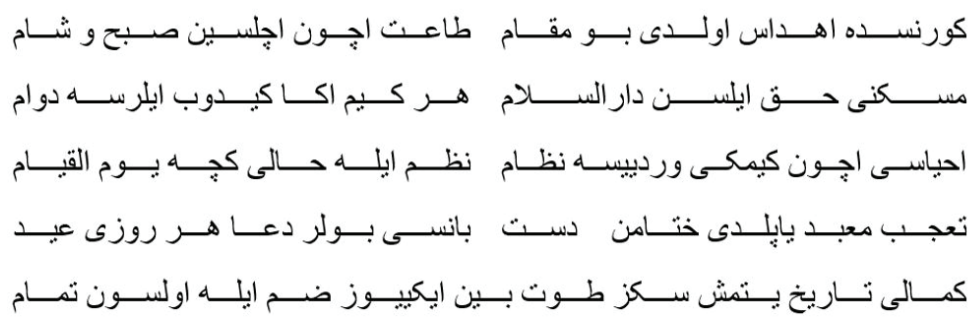

سنه 1278

\section{Metnin okunuşu:}

Görnesde ihdas oldu bu makam taat içun açılsın subh-u şam

Mesken-i hak eylesin darü's-selam her kim ona gidip eylerse devam

Ihyası içun kim ki verdiyse nizam nazm eyle hali geçe yevme'l-kıyam

Te'accüb-i mabed yapıldı hitâmın desti banisi bulur dua her ruz-i 'iyd

Kemal-i tarih yetmişsekiz tut bin ve ikiyüz zamm ile olsun temam

$1278 / 1861$

\section{Metnin günümüz Türkçesine aktarılmış şekli:}

Görnes'de sabah ve akşam itaat için açıldı bu camii

Camiyi barış yurdu eylesin hak, her kim ona gidip devam ederse

Ihyası için kim verdiyse nizam tertip ile kıyamet gününde sevdiği ile beraber olsun.

Hayranlık verici mabedi yapıp bitiren kişiye, banisine her bayram günü edilir dua Tamamlanma tarihi 78'i tut ve ona 1200 ilave et tamam. 
Cami hakkında ortaya çıkartılan ve birbirinin tamamlayıcısı niteliğindeki üç arşiv nüshası incelendiğinde Çıldır Sancağı kaymakamı Es-seyyid Abdurrahman Ziya, başkatibi Es-Seyyid Mehmet Ragıp, nüfus bakanlığı azası Es-Seyyid Mehmet Kemalettin, Oltu Kazası'nın iyi huylu halifesi Es-Seyyid Ali Rıza'nın isimlerinin yer aldığı üç nüshalık kaydı yazan yazı işleri kâtibi Mehmet Halid'in padişah hazretlerinin vakıflarını kontrol eden yüce (bakanlık) makamına gönderdiği belgede, Tavusger Kazası'ndaki Görnes isimli köyde rahmetli olan Saliha Hanım'ın inşa ettiği caminin imamlık ve hatiplik vazifesini yüce padişahın izniyle yöneten Ali oğlu Abdullah'ın vefat etmesi üzerine boşalan iki görev için rahmetlinin büyük oğullarından 36 yaşındaki Yusuf, 31 yaşındaki Mahmut, 6 yaşındaki Şaban, 19 yaşındaki Recep ve on yaşındaki Arif' in isimleri geçmiştir. Arif' in doğumuna dair Defterhane'de bir kayıt olmamasına karşılık izin kaydının düzenlenmesi uygun bulunmuştur. Bu isimlerden imamlık görevine yetenekli ve becerikli birine bağımsız bir şekilde verilmesi, hatipliğin ise diğer oğullarının ortaklaşa yapılması şart koşulmuştur ${ }^{48} \mathrm{Bu}$ hususta, adı geçen oğullardan Yusuf, Şaban, Mahmut ve Recep'in imamlık vazifesinde yeterli bilgiye, beceriye ve yeteneğe sahip olmadıkları, çiftçilik hizmetiyle uğraşmaları sebebiyle rıza gösterip talep ederek paylarını (vazifeyi) Şeriat (hâkim, kadı, mahkeme) önünde küçük kardeşleri Arif'e bıraktıkları anlaşılmaktadır. Ancak Arif' in yaşının küçük olması sebebiyle ergenlik yaşına ulaşıncaya kadar görevi yürütemeyeceği aşikardır. Bu sebeple göreve gelecek kişinin kaza meclisinde "meclis azası" hazır oldukları hâlde sınama (sınav) ile layık olma durumu oldukça açık ve görünür vaziyettedir. Bahsi geçen köyün nüfus defterlerinde, yedinci evin üçüncü numarasıyla kayıtlı 47 yaşındaki askerlik hizmetini gerçekleştirmiş, rahmetli (Abdullah oğlu Ali)'nin ana-baba bir kardeşi Molla Halil'in imamlık ve hatipliğe vekâleti, yüce ve ulu padişahın katına sunulmuş ve bildirilmiştir. Yine de emir ve buyruk sahibi, ululuğa ulaşan padişahın el yazısıyla emir vermesi beklenmektedir. Bu metin, şerefli recep ayının 20. Günü 1073’te (1861-1862) yazılmış ve cümle büyük Osmanlı Devleti'nin aciz duacısı, padişahın kulu Es-seyyid Ali Rıza ismiyle nihayetlendirilmiştir.

Kadın bir bani tarafından dikdörtgen plan şemasında, ahşap destekli olarak inşa ettirilen caminin harim mekân1, 7.27 x $8.42 \mathrm{~m}$, son cemaat yeri ise $9.17 \times 4.64 \mathrm{~m}$ ölçülerindedir. Yapının duvar kalınlığı da 0.70 m'dir (G. 5). 


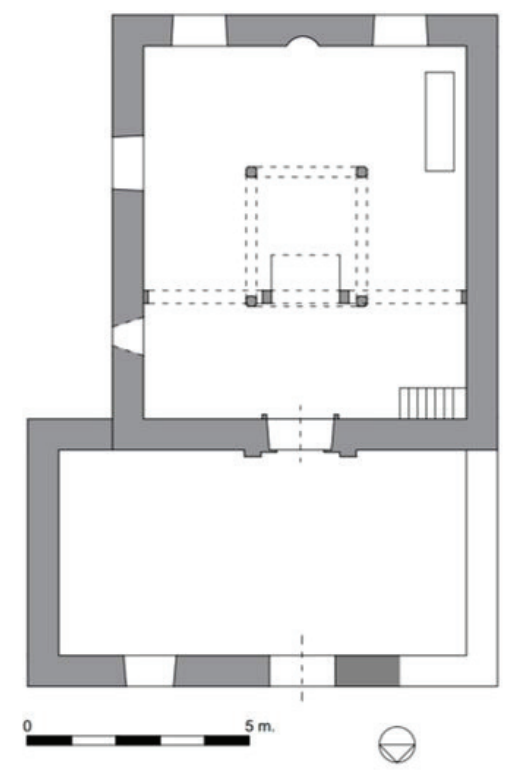

G. 5: Cami Plan Şeması (Gökler, 2020)

Bugün tamamen yıkılma tehlikesiyle karşı karşıya kalan caminin beden duvarları moloz taş ve ahşap hatıllar ile örülmüştür. Birbirini tekrar eden duvarların güney, doğu ve kuzeyinde açılan dikdörtgen formlu pencereler ile iç mekânın 1şık alması sağlanmıştır. Bu pencerelerden kuzeydoğudaki mahfil seviyesinde olup iç bölüme mazgal olarak yansıtılmıştır. Yapının kuzeyinde büyük bir bölümü yıkılmış olan kapalı son cemaat yeri bulunmaktadır. Son cemaat yerinin özellikle batı k1smının medrese odası olarak kullanıldığı yöre halkı tarafından ifade edilmiştir. Bu durum Karadeniz camilerinde de oldukça yayındır. Zemin kotunun altında kalan yapının son cemaat yerine bir iki basamaklı merdivenle ulaşılan basık yuvarlak kemerli bir kapı ile geçilmektedir. İç bölümünde tamamen otların bittiği bu alan ölçüleriyle caminin dışına taşmaktadır. Son cemaat yerinden harime geçiş sağlayan basık yuvarlak kemerli kapı açıklı̆̆1, dıştan yuvarlak kemerle kuşatılmıştır. Üstte düz bir tepelikle sonlanan kapı, dışa doğru da taşırılarak vurgulanmıştır.

Caminin harim mekânı oldukça kötü bir durumda olup beden duvarları gösterişten uzak bir iç alan sunmaktadır. Giriş kapısı aksına yerleştirilen ve duvara oyulan sade mihrap nişinin ortasında Âl-i İmrân suresinin 37. ayeti olan "Küllema Dehale Aleyha Zekeriyyel Mihrab ${ }^{49}$ " yazısı ile karşılaşılmaktadır. Mihrabın kavsarasına ise tam olarak işlenememiş olsa da mukarnas izlenimi verilmeye çalışılmıştır.

49 “Zekeriyyâ onun bulunduğu yere, mâbeddeki odaya her girdiğinde”, erişim 27 Temmuz 2021 https://kuran. diyanet.gov.tr/tefsir/\%C3\%821-i\%20\%C4\%B0mr\%C3\%A2n-suresi/330/37-ayet-tefsiri 
Mihrabın batısında bulunan ahşap minber, klasik minber formu anlayışının dışında olsa da süsleme özellikleriyle dikkat çekmektedir. Harimin güneydoğu köşesini kapatan kare gövdeli vaaz kürsüsü, yuvarlak kemerlerle birbirine bağlanan 4 ayak üzerinde yükselmektedir. İbadet alanının kuzeyini kaplayan kadınlar mahfili, kare kaideli ve başlıklı, silindirik gövdeli ahşap sütunlar tarafından taşınmaktadır. Kuzeybatıdaki düz bir merdivenle ulaşılan mahfilin kare balkonu, mahfil korkulukları ve mahfil kirişi bezemeleriyle yapının tarihi geçmişini ve özgünlüğünü perçinlemektedir. Camiyi içten örten ve dört ahşap sütun tarafından desteklenen ahşap tavan, dıştan toprak dam ile koruma altına alınmıştır (G. 6-G. 20) ${ }^{50}$.
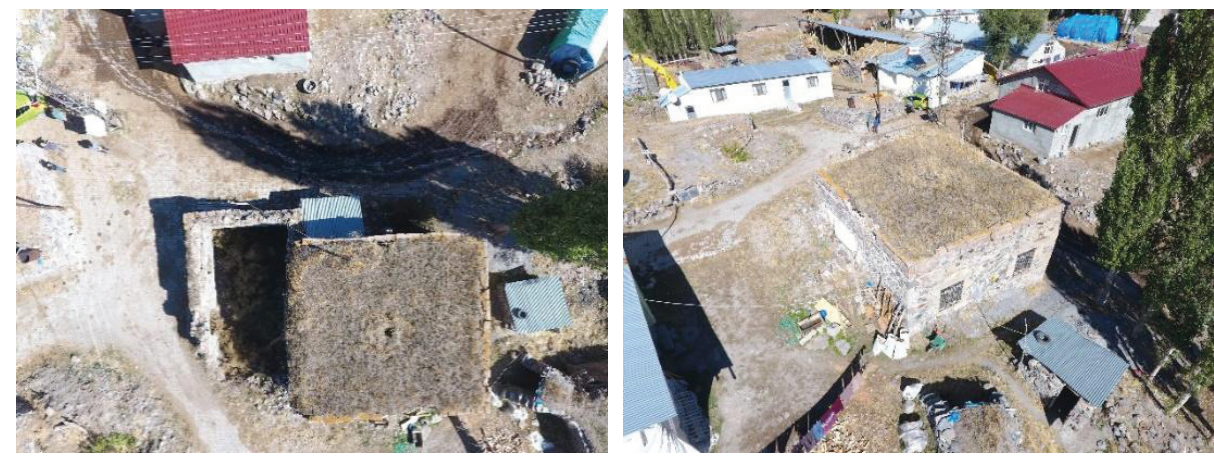

G. 6: Caminin Üstten Görünümü (Gökler, 2020)

G. 7: Caminin Güneybatı Cephesi (Gökler, 2020)
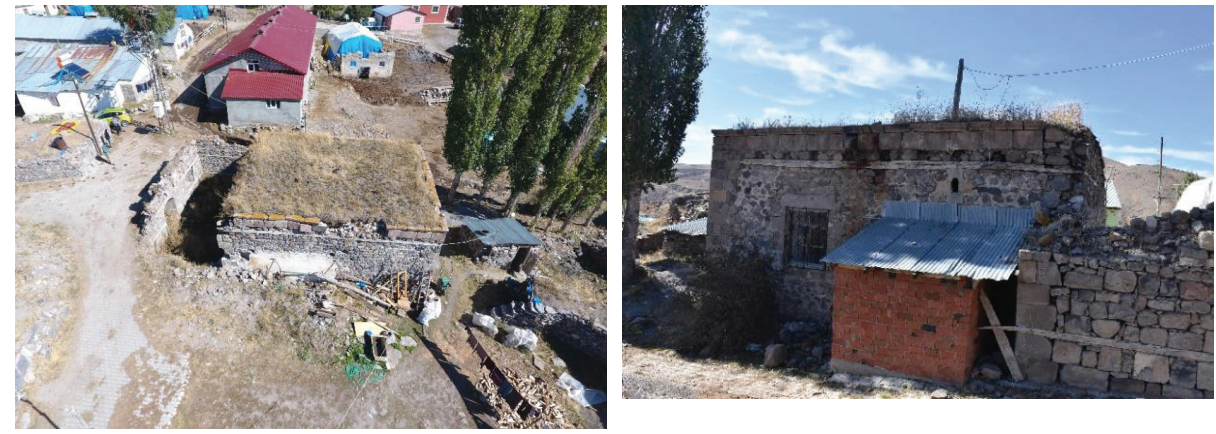

G. 8: Caminin Batı Cephesi (Gökler, 2020)

G. 9: Caminin Doğu Cephesi (Gökler, 2020)

50 Güvenlik Köyü Camii’ne ait "google eart" dışındaki bütün hava (drone) fotoğrafları, görselleri ve plan çizimi 2020'de Burak Muhammet Gökler, mimari elemanların süsleme çizimleri ise Muhammed Emin Doğan tarafından 2021 yılında gerçekleştirilmiştir. Farklı kaynaklardan alınan görsellerin bilgileri görsel altına eklenmiştir. 

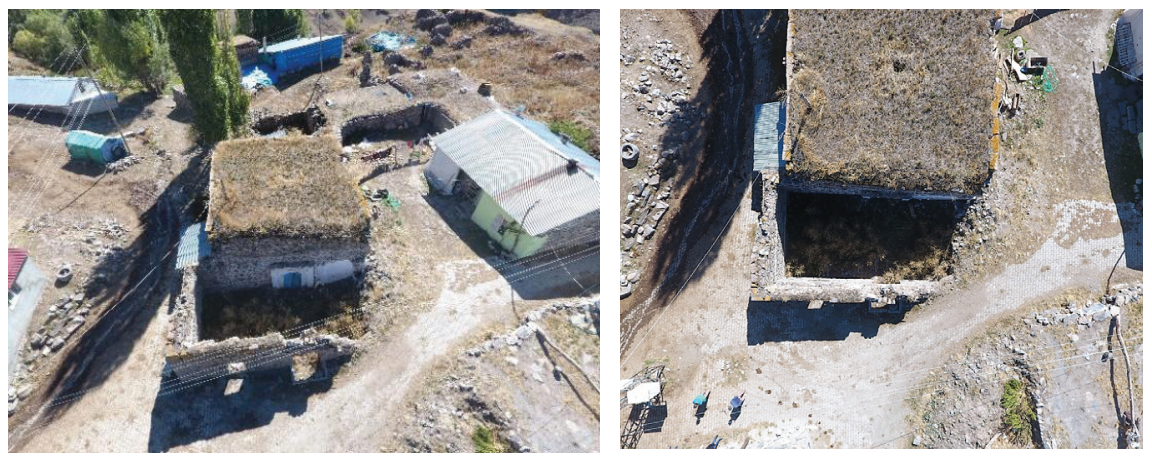

G. 10: Caminin Kuzey Cephesi (Gökler, 2020)

G. 11: Son Cemaat Yeri (Gökler, 2020)
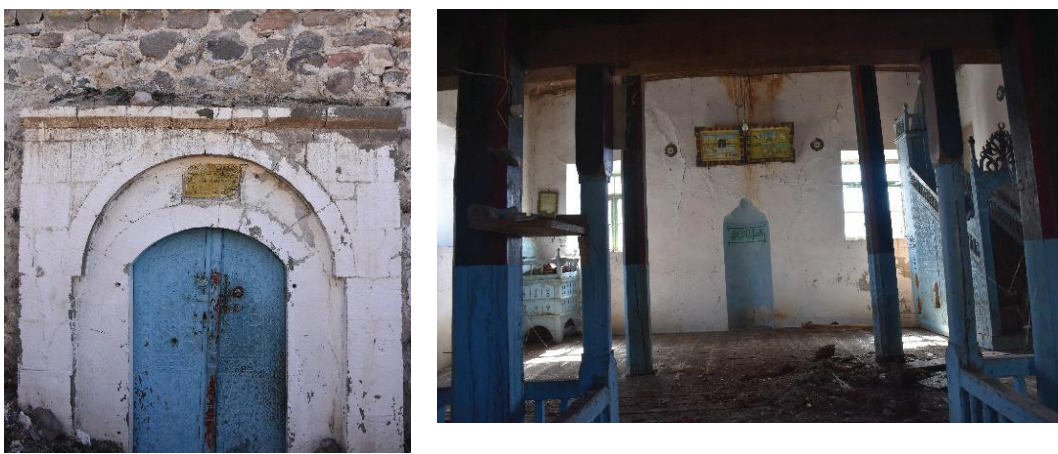

G. 12: Harim Giriş Kapısı (Gökler, 2020)

G. 13: Harim Mekânı (Gökler, 2020)
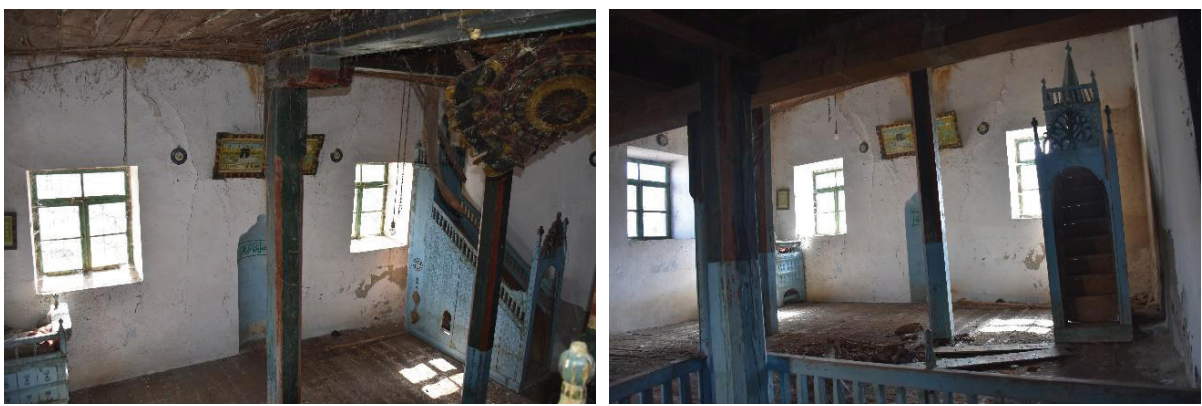

G. 14: Harim Mekânı (Gökler, 2020)

G. 15: Harim Mekânı (Gökler, 2020) 

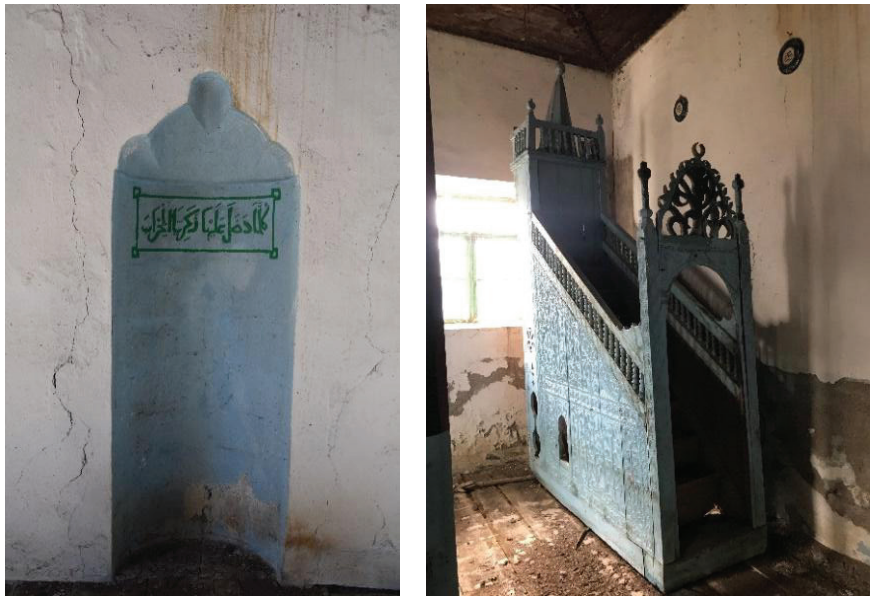

G. 16: Caminin Mihrabı (Gökler, 2020)

G. 17: Caminin Minberi (Gökler, 2020)
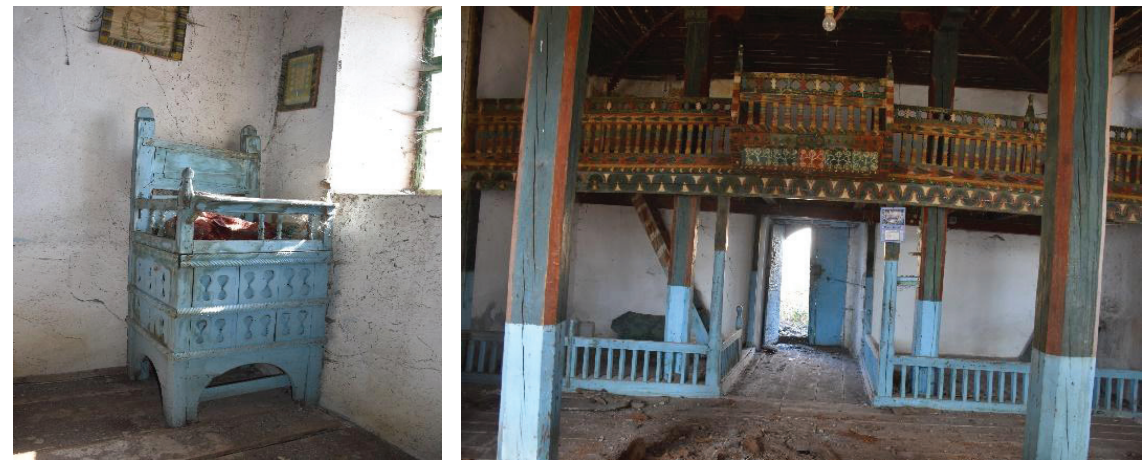

G. 18: Vaaz Kürsüsü (Gökler, 2020)

G. 19: Kadınlar Mahfili (Gökler, 2020)

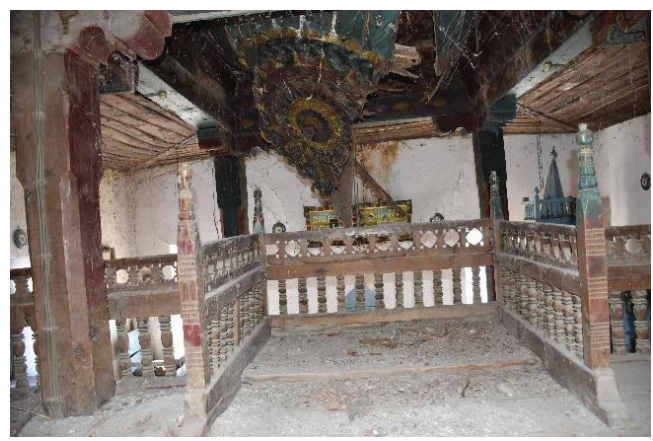

G. 20: Kadınlar Mahfili ve Üst Ötü (Gökler, 2020)

\section{Süsleme Özellikleri}

Caminin dış mimarisi bezeme açısından sade bir anlayışa sahipken harim giriş kapısından başlayan tezyinat anlayışı, minber, mahfil, vaaz kürsüsü ve tavan göbe- 
ğinde kendisini göstermekte, iç mekânı canlandırmaktadır. İki kanattan oluşan ahşap kapının kanatları etrafı zikzaklarla sınırlandırılmış ikişer panoya bölünmüştür. Alt pano hasır örgü ile hareketlendirilirken üst panoda nar ağaçları görülmektedir. Panolar birbirinden badem geçmelerle ayrılırken en dıştan zikzak ve badem geçmelerle sinırlandırılmıştır (G. 21, G. 22)
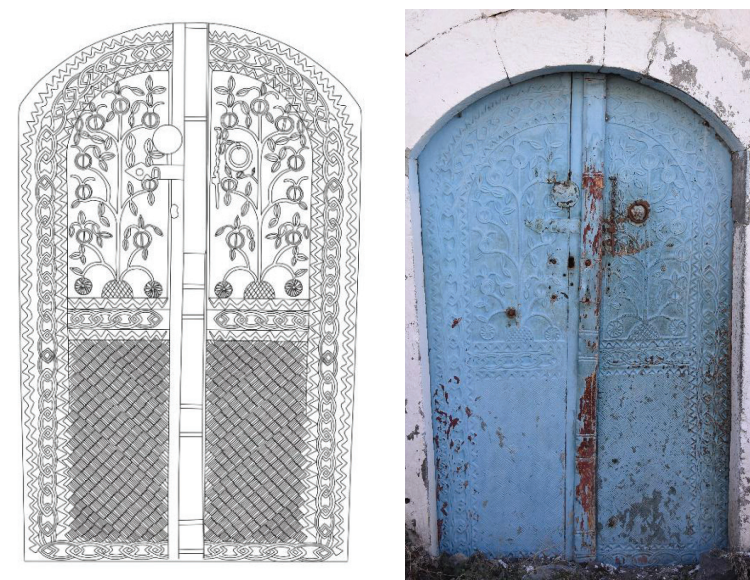

G. 21: Kap1 Kanatları (Doğan, 2021)

G. 22: Kap1 Kanatları (Gökler, 2020)

Kapı kanatlarındaki bezemeleri büyük ölçüde tekrar eden bir diğer mimari öge minberdir. Minber kapı tacının ortası dalga motifleriyle süslenmiş, etrafı ise hilal motifleriyle kuşatılmıştır (G.23, G. 24).

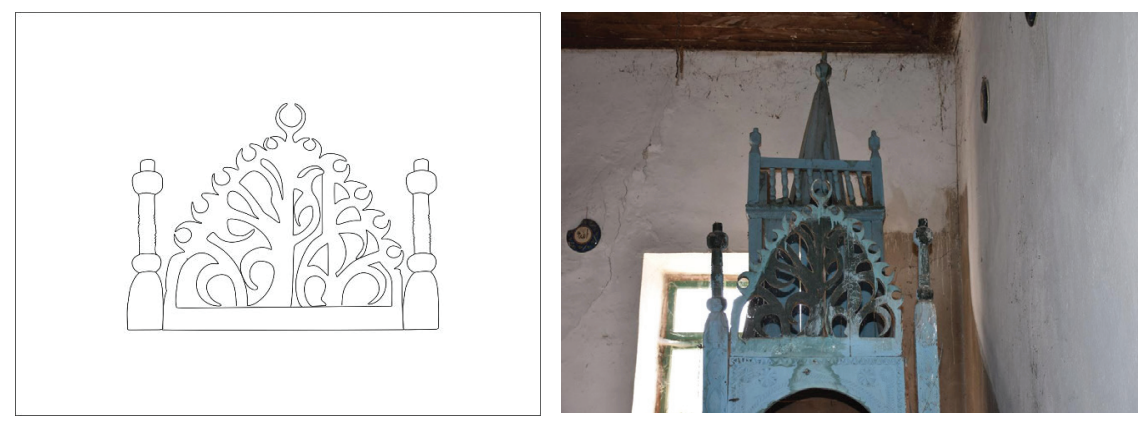

G. 23: Minber Kapı Tacı Süslemesi (Doğan, 2021)

G. 24: Minber Kap1 Tac1 Süslemesi (Gökler, 2020)

Minberin en önemli bezemeleri aynalık ve süpürgeliğin bir bütün içerisinde verildiği cephede yoğunlaşmıştır. Sınır hattı badem geçme ve zikzaklarla belirlenen, toplamda 11 panoya taksim edilen cephenin altı panosu alt, beş panosu üst kısmı oluşturmaktadır. Panolardan dokuzu nar ağaçlarıyla, biri kademeli üçgenlerle dekore edilirken etrafı balıksırtıyla çevrelenen son pano ise üzerinde narların bulunduğu 
dekoratif bir açılıkla kompoze edilmiştir. İkili zencerek geçmeyle hareketlendirilen kapı sövesinden başlayan ve köşke kadar devam eden korkuluk bölümü, boğumlu torna korkuluklarla hareketlendirilmiş, alttan ise zencerek geçmelerle desteklenmiştir.

Mimari ögenin köşk ve köşk altı bölümü kesintisiz biçimde birbirine bağlanmakta ve bir birlik teşkil etmektedir. Köşkün üst bölümü, boğumlu korkuluklar ve halat örgüyle tamamlanırken köşk atlında, dekoratif bir gülabdan ve çiçek rozetiyle karşılaş1makta, kompozisyon yandan zencerek geçme ile sınırlandırılmaktadır (G. 25, G. 26).

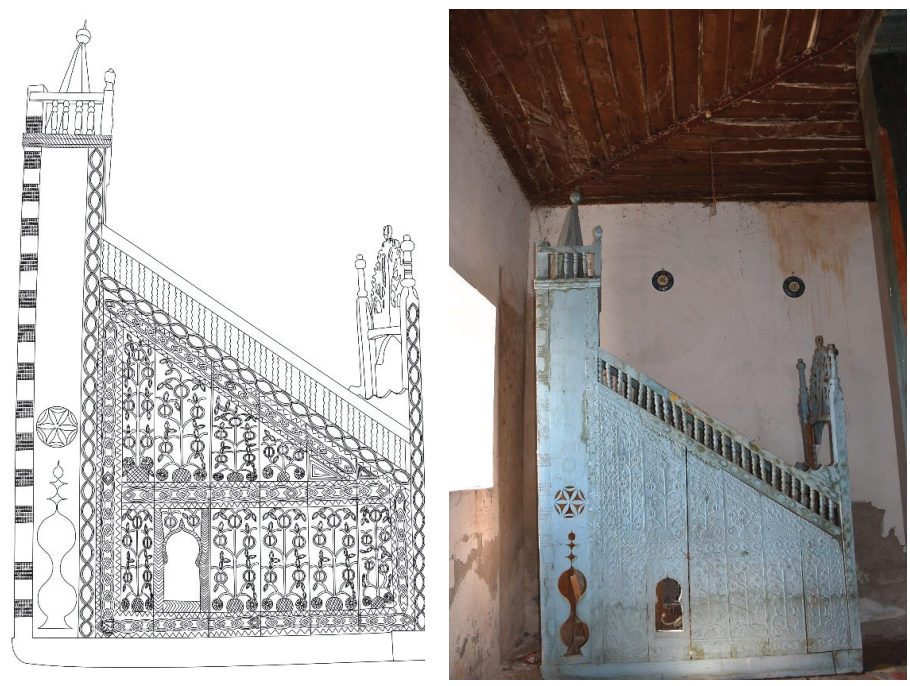

G. 25: Minber Süslemesi (Doğan, 2021)

G. 26: Minber Süslemesi (Gökler, 2020)

Bezemeleriyle harime canlılık katan mahfil kirişi, balkonu ve korkulukları kök boyalarıyla da iç mekânı renklendirmektedir. Kiriş üzerine zikzaklarla birlikte işlenen kademeli kıvrımlı hat mahfil boyunca akmaktadır. Balkonda eşkenar dörtgenler, halat örgü, balıksırtı ve nar ağaçları alanı tezyin etmektedir. Korkuluk kısmında ise papyon geçmeler, ok ucu ve boğumlu korkuluklarla karşılaşılmaktadır (G. 27, G. 28). Vaaz kürsüsünde de balıksırtı ve halat örgünün tekrar edildiği görülmektedir (G. 29, G. 30).
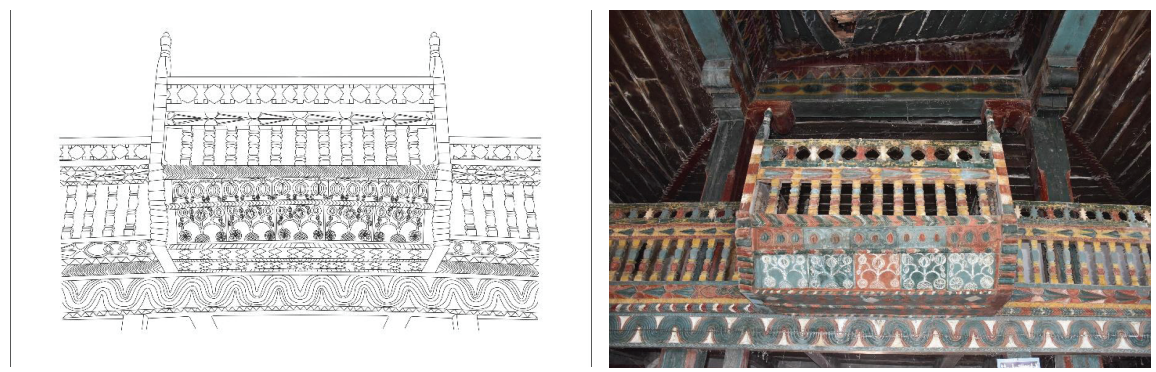

G. 27: Mahfil Süslemesi (Doğan, 2021)

G. 28: Mahfil Süslemesi (Gökler, 2020) 

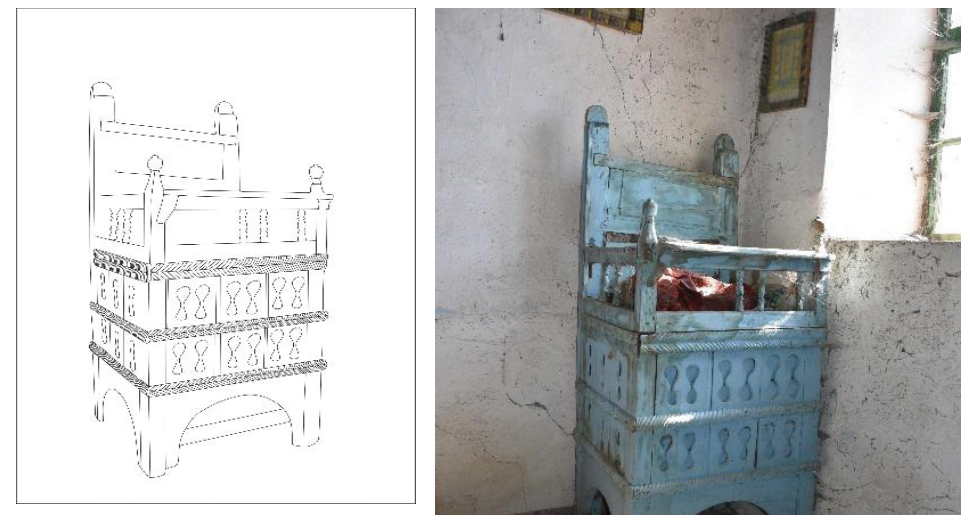

G. 29: Vaaz Kürsüsü Süslemesi (Doğan, 2021)

G. 30: Vaaz Kürsüsü Süslemesi (Gökler, 2020)

İbadet mekanının son bezemeli alanı ahşap tavandır. Kare içerisine alınarak vurgulanan tavan merkezindeki geometrik ve bitkisel kurgulu göbek madalyonu, büyük ölçüde tahrip olmuştur. Madalyonun merkezindeki gülbezek ve nar çiçeği birleşimindeki kompozisyonun etrafı üçgenler, basit yapraklar ve balıksırtı örgeleriyle dışa doğru genişlemektedir. Bu genişletmeyi devam ettiren iki dairesel bordürün içerisindeki damga motifleri oldukça dikkat çekicidir. Tavanın içe bakan yüzeyleri ise badem geçme, üçgen ve nar motifleriyle dolgulanmıştır (G. 31, G. 32).

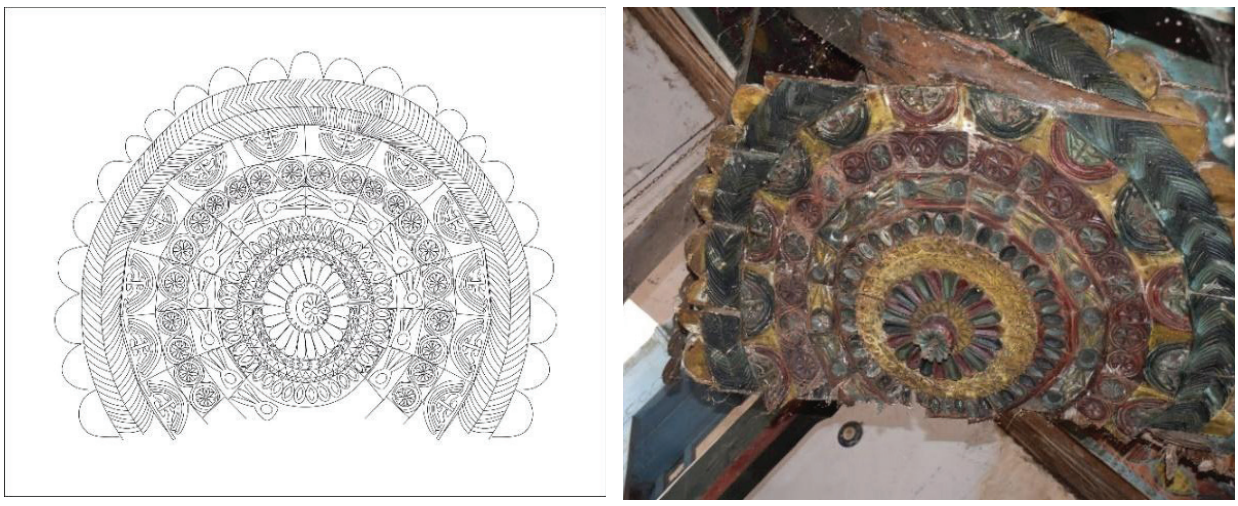

G. 31: Tavan Süslemesi (Doğan, 2021)

G. 32: Tavan Süslemesi (Gökler, 2020)

\section{Değerlendirme}

Doğanın insanlığa sunduğu en önemli ve kullanışlı maddelerden birisi ağaç/ahşaptır. İnsanlığın barınma başta olmak üzere pek çok ihtiyacını karşılayan ahşap, mimarinin gelişmesinde de etkin bir rol oynamıştır. Türklerin çadır ve kurgan mimarisinde kullandığı ahşap bilgisi el sanatlarına, savaş aletlerine, evlerine, inançları doğrultusunda tapınak ve ibadet yerlerine de yansımıştır. Türklerin, İslamiyet'le tanışması 
ve cami mimarisini tanıması, inşa edecekleri yapıları daha önceden aşina oldukları ahşapla birleştirmişlerdir. Arap Yarımadası'nda da ahşap destek kullanılmıştır. Fakat en nadide örnekler Türk ve İslam Devletleri tarafindan ortaya konulmuştur. Hz. Muhammed döneminden sonra Emeviler 'den ve Abbasilerden günümüze sağlam olarak ulaşmış bir yapı söz konusu değildir. Ahşap destekli eserler konusunda referans nokta şüphesiz Karahanlı Devleti olmuştur. Karahanlılar'dan sonra ise Anadolu Selçuklu ve II. Beylikler, Osmanlı’yı etkilemiştir.

Osmanlı İmparatorluğu'nun erken ve klasik sonrasındaki Batılılaşma dönemlerinde sayısı oldukça fazla olan ahşap destekli yapılar, Anadolu'nun geneline yayılmış bir vaziyettedir. Narman'da değerlendirmeye alınan Güvenlik Köyü Camii, Batılılaşma sürecinde ahşap destekli olarak inşa edilmiş küçük ebatlardaki tipik bir örnektir ${ }^{51}$.

Camiyi ahşap destekleri dışında değerli kılan en önemli husus, kitabesi ve arşiv kayıtlarıdır. 1861 tarihli sülüs hatlı Osmanlıca kitabe, fâilâtün / fâilâtün / fâilün vezninde ele alınmış ve köy camisi için itina ile yazılmıştır. 1861-1862 yıllarında kâtib Mehmed Halid tarafından yazılan üç nüsha hâlindeki arşiv vesikalarındaki bilgiler birbirinin tekrarı ve tamamlayıcısı niteliğindedir. Arşiv kaydında Saliha Hanım tarafindan inşa ettirilen caminin imamlık ve hatiplik vazifesi de Ali bin Abdullah tarafından yürütülmüsşür. Ali bin Abdullah'ın vefatı üzerine beş oğlundan birinin geçmesi hususunda bilgi, birikim, tecrübe ve yaş şartının arandığı görülmektedir. Dört oğlunun da bu şartları taşımaması, küçük oğlu Arif'in ise yaşını doldurmamış olması sebebiyle adalet ve liyakata göre görev, kardeşi Molla Halil'e tevcih edilerek son karar padişaha bırakılmıştır.

51 Ahşap destekli benzer örnekler içerisinde şu camiler sayılabilir: Erzurum'da Ali Paşa Camii (1570), Aşağı Habip Efendi Camii (XVIII yy.), Aşağı Mumcu Camii (XVIII.yy), Ayaz Paşa Camii (1560), Gürcü Mehmet Paşa (1648), Habib Efendi Camii (1702) İhmal Camii (1715) Kırmacı Camii (1771), Köseler Camii (1771), Esat Paşa Camii (1830), Mahmudiye Camii (1842) Taş Camii 1905), Zeynel Camii (1748), Tahta Camii (1738), Yeğenağa Camii (1661), Yukarı Habip Efendi Camii (1702), Molla Kaya Camii (1753), Kırmac1 Camii (1771), Kemhan Camii (1605), Kavak Camii (XVIII. yy), Karaköse Camii (1904), Gümüşhane'de Şiran Araköy Camii (1870), Seydibaba Köyü Camii 1797), Bayburt’ta Konursu Camii (1812), Zahit Efendi Camii (1514-15), Dağçatı Köyü Camii (1806), Buğdaylı Camii (1835), Değirmencik Köyü Camii (1899) Gökler Köyü Camii (20. Yy), Trabzon'da Bahçekaya Mahallesi Camii, Arsin Büyük Camii, Artvin'de Orta Camii (1783), Kocabey Camii (1890), Yaylalar Camii (1891), Bulanık Köyü Camii, Giresun'da Bektaş Bey Camii (1816), Orta Mh. Camii (1874), Yeniköy Camii (1836), Rize’de, Cimil Köyü Hapinç Camii (1896) ve Meşeköy Camii (1916) gösterilebilir. Hüseyin Yurttaş, Haldun Özkan, Zerrin Köşklü, vd., Yolların, Suların ve Sanatın Buluştuğu Şehir Erzurum (Ankara: Kariyer Matbaacılık, 2008), 60-90; Haldun Özkan, Hüseyin Yurttaş, Ortaçağ'dan Günümüze Gümüşhane (Gümüşhane: Gümüşhane Valiliği Yayınları, 2012), 101-102, Haldun Özkan, "Bayburt Konursu Ulu Camii ve Çeşmesi”, Sanat Dergisi 13 (2008), 57-66; erişim 15 Ocak 2021, https://karadeniz.gov.tr/zahit-efendi-camii/; Haldun Özkan, "Bayburt Dağçatı Köyü Camii ve Çeşmesi”, Güzel Sanatlar Enstitüsü Dergisi 31 (2013), 119-135; Süleyman Çiğdem, Haldun Özkan, Hüseyin Yurttaş, Tarihi ve Kültürel Varlıklarlyla Bayburt (Bayburt: Bakütam Yayınları, 2020), 210, 217-218, 223, erişim 15 Ocak 2021; https://karadeniz.gov.tr/kulturel-varliklar-2/?vilayet=5\&kaza=0\&tip=5\&arama=; Osman Aytekin, “Artvin'deki Mimari Eserler” (Doktora Tezi, Yüzüncü Yıl Üniversitesi, 1996), 103-117, 203-207, 225-228; erişim 15 Haziran 2021, https://karadeniz.gov.tr/bulanik-koyu-camii/; erişim 15 Ocak 2021, https:// karadeniz.gov.tr/kulturel-varliklar-2/?vilayet $=2 \& \mathrm{kaza}=0 \&$ tip $=5 \&$ arama $=$ camii\&sahife $=3$ 
Yapıyı ön plana çıkartan bir diğer husus giriş kapısı ve ahşap tezyinat kurgusudur. Yoğun tezyinatı ile ön plana çıkan ahşap çift kanatlı ahşap kapı, panolara ayrılarak üstte yuvarlak bir tepelikle sonlanmaktadır (G. 33). Benzer kapı örnekleri Doğu Karadeniz Bölgesi camilerinde yaygın olarak kullanılmaktadır. Rize İkizdere’de Bayırköy Ekşioğlu Camii (1899), Trabzon'da Saraçlı Camii ve Artvin'de Aşağımaden Camii52 kapıları verilebilecek birkaç örnek arasındadır (G. 34).
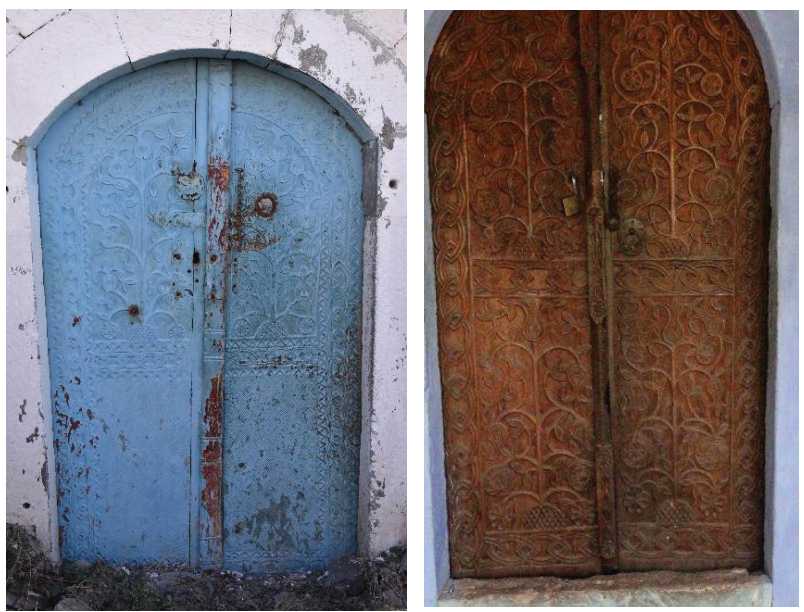

G. 33: Ahşap Kapı Kanatları (Güvenlik Köyü Camii, Gökler, 2020)

G. 34: Artvin Aşağımaden Camii (karadeniz.gov.tr)

Kapı kanatlarından başlayan süsleme programları ise minber, mahfil ve tavanda bitkisel, geometrik ve nesnesel bezemeler olarak ahşap malzemenin ve süslemenin bol olduğu Karadeniz camileri ile büyük benzerlik göstermektedir. Bitkisel bezemenin baskın olduğu yapıda bir cennet meyvesi olan nar motifi ${ }^{53}$, kapı kanatlarında, minberde (G. 35), mahfilde ve tavanda oyma-kabartma tekniği ile kendine uygulama alanı bulmuştur ${ }^{54}$.

52 Erişim 1 Haziran 2021, https://karadeniz.gov.tr/

53 Kur'an-1 Kerim'de En'am suresi 99. ayet, 141. ayet ve Rahman suresi 68. ayet olmak üzere üç farkl1 yerde adı geçen narın cennet meyvesi ve dünya nimeti olduğundan bahsedilmektedir. Nar ağacı ve meyvesi birçok medeniyette doğurganlık, sağlık, bereket ve zenginliğin sembolüdür. Detaylı bilgi için bk. Sibel Arık, "Türk Dokumacılık Sanatında Nar Motifi”, Uluslararası Ínsan Bilimleri Dergisi 6 (1) (2009), 583-593.

54 Motifin benzer örneklerine Erzurum'da Çifte Minareli Medrese'de rastlanmaktadır. Nar, medresenin giriş cephesinde tepesinde kartal, altında ise ejder figürü olan hayat ağacı motifinin yaprak uçlarına yerleştirilmiştir. Orta Asya Türk inancında, yer ile gök arasındaki bağlantıyı sağlayan kutsal ağacın narla işlenmiş olması, "Türklerdeki ağaç kültünün ve bu külte bağlı olarak gelişen hükümdar simgesinin uzantısı olarak değerlendirilmektedir”. Bk. Ersel Çağlıtütüncigil, “Türk Süsleme Sanatında Nar: "Form, Köken ve İkonografik Anlamı”, Türklük Bilimi Araştırmaları 33 (2013), 72. Bunun dışında İspir Armutlu Mahallesi Camii’nde (1914), Trabzon Çaykara Filak Mahallesi Camii’nde (1813), Raziye Çiğdem Önal ve Zerrin Köşklü, “Trabzon'da Geç Dönem Osmanlı Camilerinde Ahşap Mihraplar”, Sanat Tarihi Dergisi 29/2 (2020), 711. Köprübaş1 Beşköy Yılmazlar Mahallesi Camii'nde, Çaykara Maraşlı Köyü Camii'nde (1811) (G. 36), Dernekpazarı Kondu Mahallesi Camii’nde (1821), Demet Taşkan, “Trabzon İli Camilerinde Ahşap Minberler” (Doktora Tezi, Gazi Üniversitesi, 2016), 720. Çaykara Taşkıran Köyü Camii’nde (1897), Dernekpazarı Taşçılar Köyü Camii’nde (1804), Ogün Küçük, “Trabzon’un Çaykara, Dernekpazarı, Hayrat ve Of İlçelerindeki Osmanlı 

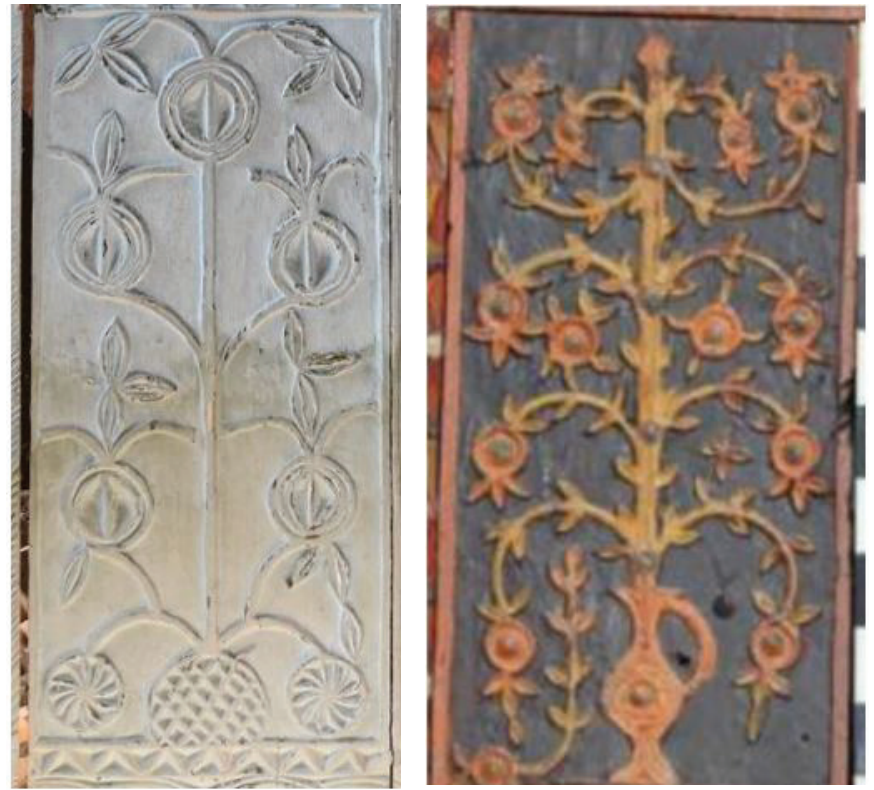

G. 35: Minber Cephesindeki Nar Ağacı (Güvenlik Köyü Camii, Gökler, 2020)

G. 36: Trabzon Maraşlı Köyü Camii (D. Taşkan,

“Trabzon İli Camilerinde Ahşap Minberler”, 147)

Bitkisel bezemenin bir diğeri tavan göbeğinde (G. 37) bulunan gülbezek motifidir. Gülün üsluplaştırılmış bir hâli olarak bilinen gülbezek, sanat terminolojisi içerisinde bazen gülçe olarak da isimlendirilmektedir ${ }^{55}$. Tavana aplike şeklinde uygulanan motif, koyu kırmızı ve yeşil tonlarındadır ve nar çiçeği motifi ile bir bütünlük teşkil ederek tekil bir örnek hâlini almıştır ${ }^{56}$.

Dönemine Ait Bazı Ahşap Camiler (18-19 yy)", (Yüksek Lisans Tezi, Yüzüncü Yıl Üniversitesi, 2017), 40-43, 56-59. Bayburt'ta Dağçatı Köyü Camii'nde, Özkan, Bayburt Dağçatı Köyü Camii ve Çeşmesi, 123, Rize'de Yukarı Çamlıca Köyü Camii'nde (1865), Yenice Köyü Camii’nde, Demirkapı Köyü Camii’nde, Uğrak Köyü Camii'nde karşıllaşılmaktadır.

55 Bahattin Yaman, “XIII. yüzyıl Anadolu Taçkapıları'nda Kullanılan Madalyon ve Kabaralar”, Istem 33 (2019), 129.

56 Anadolu'nun pek çok camisinde bulunan bu süslemenin benzer birkaç örneği şu camilerde görülmektedir: Trabzon'da Sürmene Karacakaya Köyü Camii (1812-1813), Araklı Kestanelik Köyü Camii, Sürmene Çamburnu Kuşluca, Mahallesi Camii (G. 38), Araklı Turnalı Köyü Camii, Taşkan, "Trabzon İli Camilerinde Ahşap Minberler”, 738-739. Taşçlar Köyü Merkez Camii (1804), Sarmaşık Köyü Camii (1809), Mithat Paşa Camii (1817), Güneykondu Mahallesi Camii (1814), Küçük, “Trabzon'un Çaykara, Dernekpazarı, Hayrat ve Of İlçelerindeki Osmanlı Dönemine Ait Bazı Ahşap Camiler”, 228, 241, 265, 281. Artvin'de Muratlı Camii (1846), Camili Camii (1855), Aytekin, “Artvin'deki Mimari Eserler”, 168-180. Hopa Camii (19. Yüzyıl), Esenkıyı Camii (1850), Demet Taşkan, “Artvin İli Borçka ve Hopa İlçeleri Camilerinde Ahşap Süsleme” (Yüksek Lisans Tezi, Gazi Üniversitesi, 2011), 45-50. Ordu Ünye'de Saray Camii (1719), Esin Özdemir, "Ordu ve İlçelerindeki Türk Dönemi Mimari Eserleri” (Yüksek Lisans Tezi, Yüzüncü Yıl Üniversitesi, 2011), 50. Ardahan Posof’ta Gönülçalan Camii (1909), Sarıdarı Camii (1924), Türkgözü Camii (1869), Ali Murat Aktemur, Posof ve Çevresindeki Tarihi Kültür Varlkkları (Erzurum: Zafer Form Ofset, 2016), 93-119. Afyon'da Aynığlu Camisinde (1797), İlyas Yaşayacak, “Afyonkarahisar'daki Ahşap Destekli Camiler" (Yüksek Lisans Tezi, Ege Üniversitesi, 2018), 165167. Gürcistan'da Akho Camii (1818), erişim 17 Nisan 2021, https://www.indigenousoutsiders.com/akho 

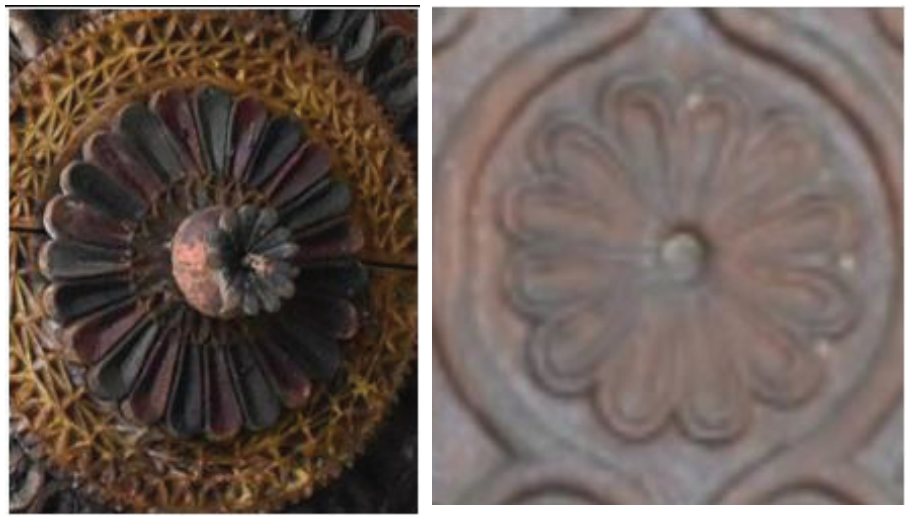

G. 37: Gülbezek Motifi (Güvenlik Köyü Camii, Gökler, 2020)

G. 38: Trabzon Çamburnu Kuşluca Camii (Yavuz Sarı, "Trabzon'un Hayrat, Of ve Sürmene İlçelerindeki Köy Camileri”, 187)

Minber köşk altına ajur tekniğinde uygulanan çiçek rozetin (G. 39) birebir kopyaları Doğu Karadeniz illerindeki camilerdedir. Bu camiler Trabzon'da Sürmene Yeniay Kuleli Camii (G. 40), Maçka Esiroğlu Beldesi Akmescit Köyü Camii, Çaykara Taşkıran Beldesi Merkez Camii, Of Saraçlı Köyü Yukarı Mahalle Camii, Of Cumapazarı Belgesi Serindere Mahallesi Camii (1883), Sürmene Dirlik Köyü Camii ${ }^{57}$, Rize'de Küçüktaşhane Camii (1891) ve Bilen Köy Camii (18. yy)'dir.
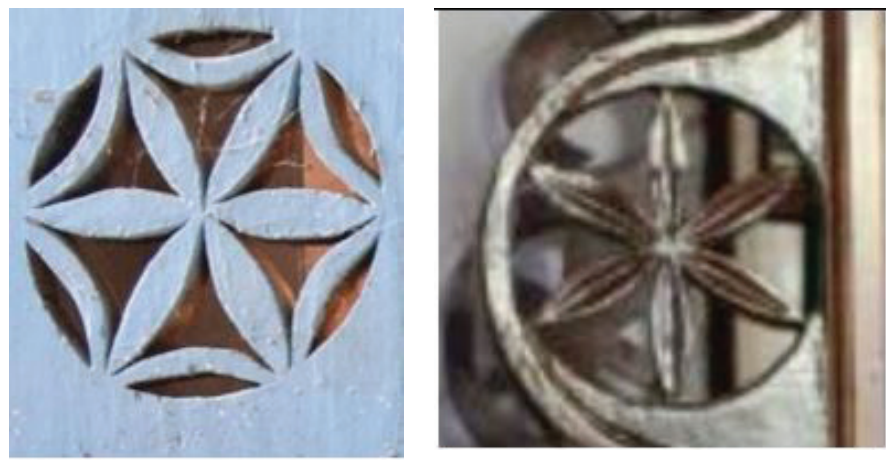

G. 39: Rozet Çiçek (Güvenlik Köyü Camii, Gökler, 2020)

G. 40: Sürmene Yeniay Kuleli: Camii (Demet Taşkan, "Trabzon İli Camilerinde Ahşap Minberler", 596)

Geometrik bezemelerin ilki genellikle Karadeniz Bölgesi camilerinde rastlanan badem geçmelerdir. Kapı kanatlarına, minbere ve mahfile işlenen badem geçmelerin (G. 41) uygulandığı farklı bir yapı Erzurum'da tespit edilememiştir ${ }^{58}$. Benzer bir an-

57 Taşkan, “Trabzon İli Camilerinde Ahşap Minberler”, 741.

58 Badem geçmeyle Bayburt Alıçlık Eski Camii’nde (1887), Çiğdem, Özkan ve Yurttaş, Tarihi ve Kültürel Varlıklarlyla Bayburt, 186. Trabzon'da Çaykara Filak Camii'nde (1813), Çaykara Çamlıbel Mahallesi Merkez Camii’nde (1888), Önal ve Köşklü, “Trabzon'da Geç Dönem Osmanlı Camilerinde Ahşap Mihraplar”, 710719. Dernekpazarı Günebakan Mahallesi Camii’nde (1869), Çambaşı Köyü Orta Mahalle Hacı Ömerli Camii 
layış minberin köşk bölüme dikey biçiminde konumlandırılan (G. 43) ikili zencerek geçmeler içinde geçerlidir ${ }^{59}$.
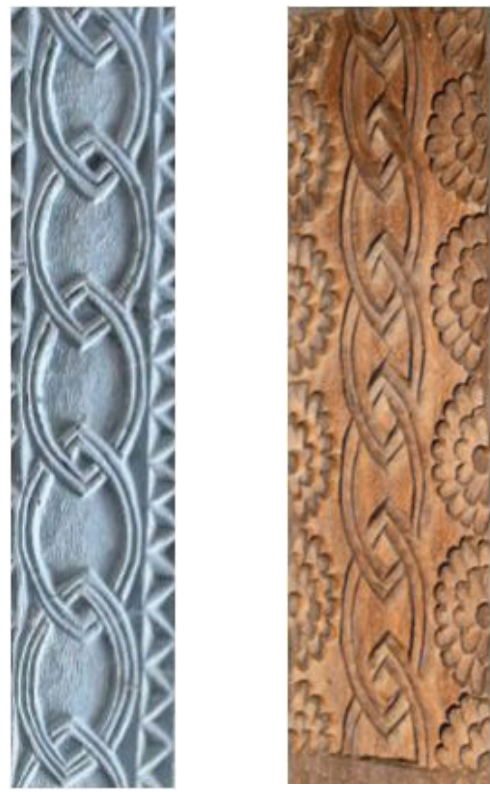

G. 41: Badem Geçmeler (Güvenlik Köyü Camii, Gökler, 2020)

G. 42: Samsun Porsuk Camii (Samsun Ahşap Camileri, 98)

(1845), Dereyurt Köyü Merkez Eski Camii (1832), Küçük, “Trabzon’un Çaykara, Dernekpazarı, Hayrat ve Of İlçelerindeki Osmanlı Dönemine Ait Bazı Ahşap Camiler”, 32, 83, 92. Of Serindere Camii'nde (1883) Hayrat Kakuşlar Camii'nde (1912), Araklı Keçikaya Köyü Camii’nde (1830), Çaykara Taşkıran Beldesi Merkez Camii'nde (1896), Araklı Turnalı Mahallesi Camii’nde (1837), Taşkan, “Trabzon İli Camilerinde Ahşap Minberler," 769. Ordu'da Fatsa Oluklu Mahallesi Sarnıç Camii (1895), Ordu İkizce Laleli (Eski) Camii (1522/1871), Ünye Kelas Mahallesi Camii (19. yy), Ahmet Ali Bayhan, Geçmişten Günümüze Ordu'nun Geleneksel Ahşap Camileri, (Ordu: Ordu Büyükşehir Belediyesi, 2019), 157, 200, 257, 259. Samsun'da Çarşamba Porsuk Köyü Camii'nde (1859) (G. 42), Samsun Ahşap Camiler, Ed. Şenler Yıldız (Ankara: Sincan Matbaası, 2011), 98. Terme Aşağı Söğütlü Mahallesi Camii’nde (19. yy) karşılaşılmaktadır. Sami Bayraktar, "Samsun ve İlçelerinde Türk Mimari Eserleri” (Doktora Tezi, Atatürk Üniversitesi, 2005), 798.

59 İkili zencerek geçmelere Trabzon'da Of Serindere Mahallesi Camii’nde (1883), Çaykara Soğanlı Köyü Üç Direk Mahallesi Camii'nde (1898), Sürmene Karacakaya Köyü Camii’nde (1813), Taşkan, “Trabzon İli Camilerinde Ahşap Minberler,” 766. Sugeldi Köyü Aşağı Mahalle Camii (1835), Dereyurt Köyü Merkez Eski Camii'nde (1832), Yavuz Sarı, “Trabzon’un Hayrat, Of ve Sürmene İlçelerindeki Köy Camileri” (Yüksek Lisans Tezi, Ondokuz Mayıs Üniversitesi, 2016), 25, 104. Samsun’da Çarşamba Porsuk Köyü Camii’nde (1869), Samsun Ahşap Camiler, 94. Tiryakioğlu Camii’nde (1867), Eyüp Nefes, “Samsun'da Ahşap Bir Osmanlı Eseri Ayvacık/Tiryakioğlu Camii”, Ondokuz Mayıs Üniversitesi İlahiyat Fakültesi Dergisi, 28 (2010), 172. Bayburt'ta Alıçlık Eski Camii’nde (1887), Çiğdem, Özkan ve Yurttaş, Hüseyin Tarihi ve Kültürel Varlıklarıla Bayburt, 186-187. Rize'de Yukarıdurak Köyü Camii’nde (1736), İkizdere Şimşirli Köyü Camii'nde (1848), Hacı Şeyh Camii'nde (1886) (G. 44) ve Pazar Ortayol Köyü Camii’nde (1896) rastlanılmaktadır. 

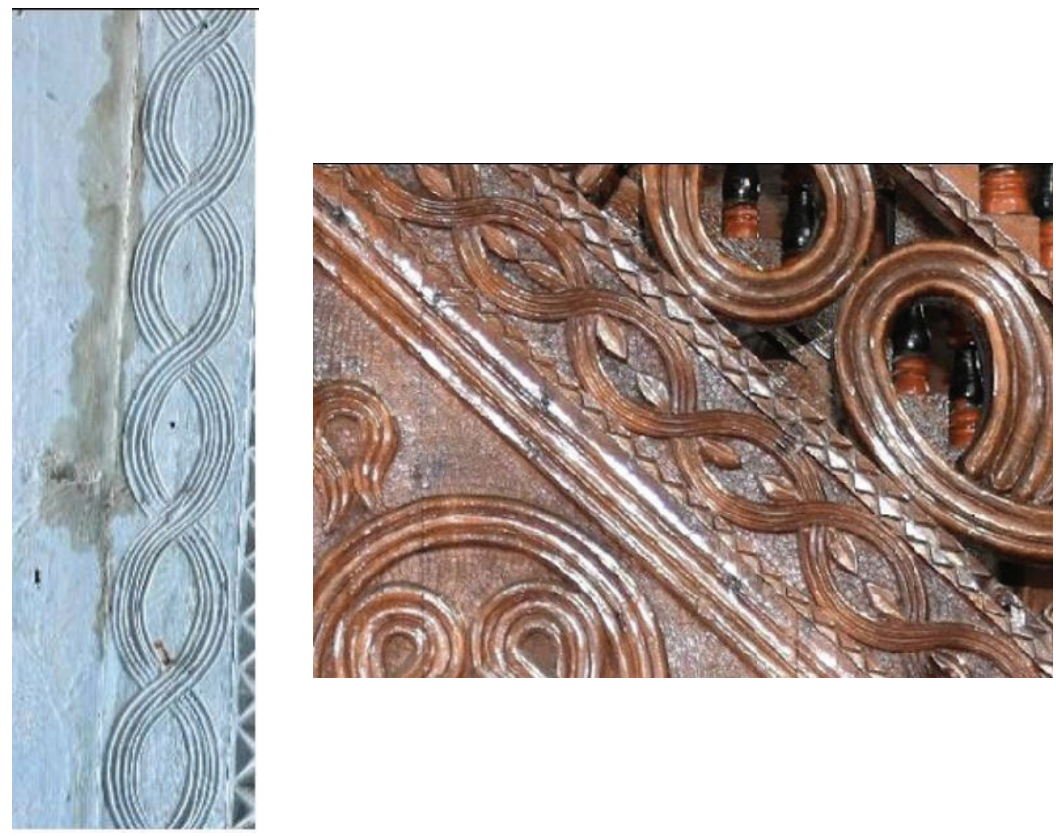

G. 43: İkili Zencerek Geçme (Gökler, 2020)

G. 44: Rize Hacı Şeyh Camii (Gökler, 2019)

Karadeniz coğrafyası ile özdeşleşmiş örgelerin başında, bölgenin karakteristik bir süslemesi olan papyon geçme gelmektedir. Güvenlik Köyü Camii'nin mahfil korkulukları hareketlendiren geçme, genelde "çantı" camilerin pencerelerinde, mahfil ve minber korkuluklarda ve vaaz kürsülerinde kullanılmaktadır ${ }^{60}$.

60 Papyon geçme (G. 45); Trabzon'da Dereyurt Köyü Merkez Eski Camii'nde (1832), Mithat Paşa Camii (1817), Sugeldi Köyü Camii (1835), Cuma Pazarı Serindere Camii (1884), Çamburnu Kușluca Camii (1893), Sarı, “Trabzon'un Hayrat, Of ve Sürmene İlçelerindeki Köy Camileri”, 25, 50, 104, 147, 172. Artvin’de Borçka Camili Köyü Camii (1855), Düzköy Merkez Camii (1850), Taşkan, “Artvin İli Borçka ve Hopa İlçeleri Camilerinde Ahşap Süsleme”, 112, 120. Giresun'da Melikli Köyü Tahtalı Camii (1807), Bektaş Bey Camii (19. yy), Faruk Narmanlı, "Giresun Camilerinde Tezyinat” (Yüksek Lisans Tezi, Ondokuz Mayıs Üniversitesi, 2018), 140, 148. Samsun'da Porsuk Köyü Camii (1869) ve Çarşamba Ordu Köyü Camii’nde (1420), Samsun Ahşap Camiler, 34, 98. Rize'de Uğrak Köyü Camii (1815) (G. 46), Çiçekli Köyü Merkez Camii (1900), Çamlık Merkez Camii (XIX. yy), Ilıca Camii (1814) içinde yer almaktadır. 

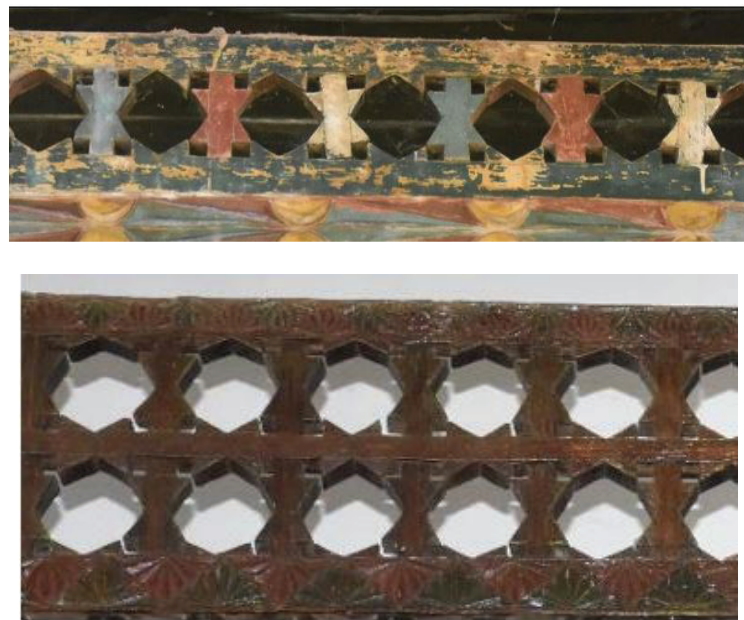

G. 45: Papyon Geçme (Gökler, 2020)

G. 46: Rize Uğrak Köyü Camii (Gökler, 2019)

Yukarıda belirtilen geometrik örgelerin dışında, ok ucu, dalga motifi, zikzaklar, üçgenler, hilaller, hasır (sepet), halat ve balıksırtı örgüler yine Karadeniz Bölgesi'nde sıç̧a kullanılan desen kurguları arasındadır.

Nesnesel tek bezeme ise minberin köşk altındadır (G. 47). Stilize gülabdan şeklindeki süsleme dekoratif bir açıklık görünümünde olup Karadeniz camilerinde minber üzerine ajur tekniği şeklinde uygulanmıştır ${ }^{61}$.

61 Gülabdan motifleriyle; Artvin'de Borçka Muratlı Camii (1846), erişim 16 Ocak 2021, https://karadeniz.gov. tr/muratli-camii/\#prettyPhoto, Trabzon'da Araklı Turnalı Köyü Camii (1842), Sürmene Çamburnu Beldesi Kuşluca Mahallesi Camii (1893), Sürmene Çamlıca Mahallesi Camii (1827), Çaykara Taşkıran Beldesi Merkez Camii (1896), Sürmene Yukarıvalı Köyü Camii (1880), Sürmene Gültepe Köyü Aşağı Kefeli Mahallesi Camii, Of Gürpınar Beldesi Hacıbayram Mahallesi Camii (1887), Taşkan, "Trabzon İli Camilerinde Ahşap Minberler”, 803. Rize Çamlıhemşin'de Yukarı Çamlıca Köyü Camii (1865), Hemşin Bilen Köy Camii (XVIII. yy), Kalkandere Hüseyin Hoca Köyü Camii (1834) ve Güneysu Ilıca Camii’nde (1814) karşımıza çıkmaktadır (G. 48). 

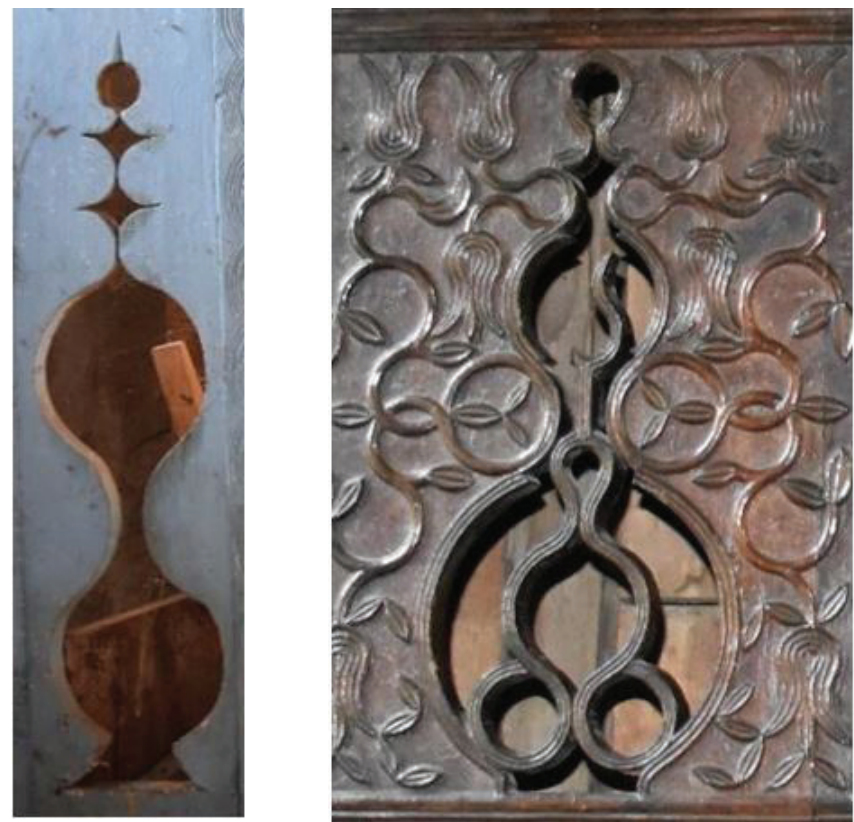

G. 47: Dekoratif Gülabdan (Güvenlik Köyü Camii, Gökler, 2020)

G. 48: Rize Hüseyin Hoca Camii (Gökler, 2019)

\section{Sonuç}

Orta Asya'dan başlayan ahşap kullanımı, Arap Yarımadası'nda İslamiyet'in gelmesi sonucunda ortaya çıan cami mimarisi ile birleşmiştir. Bu birleşim neticesinde Türk-İslam devletlerinde ahşap destekli camilerin en nadide örnekleri verilmiştir. Ahşabın kolay ulaşılabilirliği ve kısa sürede daha uygun maliyete cami yapım süreci sunması malzemeyi değerli kılmıştır. Bu nedenle Anadolu topraklarının fethinden Osmanlı'nın son dönemine kadar ihtiyaca hemen cevap veren ahşap destekli camiler sürekli inşa edilmiştir.

Günümüzde Erzurum'un Narman İlçesi sınırlarında kalan Güvenlik Köyü Camii’de ahşap destekli eserlerin Anadolu'daki tipik bir örneğidir. Yapılan arşiv çalışmaları neticesinde 1861'li yıllarda bölgenin Çıldır Sancağı'na bağlı Oltu Kazası dahilinde olduğu, köyün "Gornes" ismiyle bilindiği ve kadın bir bani tarafindan 1861'de yaptırıldığı anlaşılmaktadır. Bölgede bir kadın tarafından inşa ettirilen eserlerin sayısı az olduğu için bu durum oldukça önem teşkil etmektedir.

Güvenlik Köyü ile ilgili bir diğer durum köyün "Karadenizliler" tarafından kurulmuş olmasıdır ki bunu tescilleyen en önemli olgu, yapının kapı kanatlarında, minberinde, mahfilinde ve tavanında uygulanan süsleme programlarıdır. Erzurum camilerinde gözlemlenmeyen bu süslemelerden, nar ve gülbezek Anadolu'nun genelinde var 
olsa da ahşaba işlenişi ve Doğu Karadeniz Camilerinde sıkça tekrar edilişi ilk dikkat çeken tezyinatlardır. Bunun dışında camide karşılaşılan halat örgü, badem geçme, ikili zencerek geçme ve özellikle de papyon geçme ile dekoratif gülabdanlar sadece Doğu Karadeniz camilerinde yoğunlukta görülmesi bu kanıyı desteklemekle birlikte yapının ustasının da Karadenizli olduğuna açıkça işaret etmektedir.

Sonuçta, bugün yıkılmakla karşı karşıya olan ve Karadeniz mimarisini Erzurum'da temsil eden cami, bölge için tekil bir örnek olması nedeniyle koruma altına alınıp restorasyonu gerçekleştirilmelidir.

\footnotetext{
Hakem Değerlendirmesi: Dış bağımsız.

Çıkar Çatışması: Yazarlar çıkar çatışması bildirmemiştir.

Finansal Destek: Yazarlar bu çalışma için finansal destek almadığını beyan etmiştir.

Peer-review: Externally peer-reviewed.

Conflict of Interest: The authors have no conflict of interest to declare.

Grant Support: The authors declared that this study has received no financial support.
}

\section{Kaynakça/References}

"Hun ve Göktürk Devrinde Kurgan ve Çadırlar". Haz. Yavuz Tiryaki, Türk Dünyası Kültür Atlası İslam Öncesi Dönem. İstanbul: Türk Kültürüne Hizmet Vakf1, 1997, 54-61.

Aibai, Aihemaiti. "Uygur Geleneksel Konut Mimarisinin Ekolojik Sürdürülebilirlik Bağlamında İncelenmesi: Kaşgar Tarihi Şehri Örneği”. Yüksek Lisans Tezi, Mimar Sinan Güzel Sanatlar Üniversitesi, 2016.

Akok, Mahmut. “Kastamonu'nun Kasaba Köyündeki Candaroğlu Mahmut Bey Camii”. Belleten Dergisi X/38 (1946): 293-301.

Aktemur, Ali Murat. Posof ve Çevresindeki Tarihi Kültür Varlıkları. Erzurum: Zafer Form Ofset, 2016.

Algül, Hüseyin. "Mescid-i Kubâ". TDV İslam Ansiklopedisi, c. 29. Ankara: Türkiye Diyanet Vakfı Yayınlar1, 2004, 279-280.

Altınsapan, Erol. "Sivrihisar"eda Selçuklu Eserleri”. Eskişehir 1. Selçuklu Eserleri Semineri Bildirileri. Eskişehir: Eskişehir Valiliği Yayınları, 1990, 23-28.

Arık, Sibel. “Türk Dokumacılık Sanatında Nar Motifi”. Uluslararası Insan Bilimleri Dergisi 6 (1) (2009): 583-593.

Arslan, Muhammet. “Anadolu'da Selçuklu Çağı Cami ve Mescit Mimarisi”. Doktora Tezi, Atatürk Üniversitesi, 2017.

Aydın, Hasan Usame. Tarihi Ahşap Camiler. İstanbul: Kutlu Yayınevi, 2017.

Aytekin, Osman. “Artvin’deki Mimari Eserler”. Doktora Tezi, Yüzüncü Y1l Üniversitesi, 1996.

Ball, Warwick. Archaeological Gazetteer of Afghanistan, Tome I, Paris: Éditions Recherche sur les Civilisations, 1982.

Bayhan, Ahmet Ali. Geçmişten Günümüze Ordu'nun Geleneksel Ahşap Camileri. Ordu: Ordu Büyükşehir Belediyesi, 2019.

Bayraktar, Sami. “Samsun ve İlçelerinde Türk Mimari Eserleri”. Doktora Tezi, Atatürk Üniversitesi, 2005. 
Bozkurt, Nebi. "Çadır”. TDV İslam Ansiklopedisi, c. 8. İstanbul: Türkiye Diyanet Vakfı Yayınları, 1993, 158-162.

Bozkurt, Nebi. Mustafa Sabri Küçükaşç1. "Mescid-i Nebevî”. TDV İslam Ansiklopedisi, c. 29. Ankara: Türkiye Diyanet Vakfi Yayınları, 2004, 281-290.

Büktel, Y1lmaz. Türk Sanat Tarihi (Orta Asya'dan Anadolu'ya Türk Mimarisi). Edirne: Trakya Üniversitesi Yayınları, 1999.

Büyük Selçuklu Mirası. I. İstanbul: Türkiye Cumhuriyeti Cumhurbaşkanlığı, 2013.

Büyük Selçuklu Mirası. II. İstanbul: Türkiye Cumhuriyeti Cumhurbaşkanlığı, 2013.

Can, Y1lmaz. “Anadolu Öncesi Türk Kenti”. Türkler Ansiklopedisi, c. 3. Ankara: Ankara: Yeni Türkiye Yayınları, 2002, 259-278.

Cezar, Mustafa. Anadolu Öncesi Türklerde Şehir ve Mimarlık. İstanbul: Türkiye İş Bankası Kültür Yayınları, 1977.

Çağlıtütüncigil, Ersel. “Türk Süsleme Sanatında Nar: "Form, Köken ve İkonografik Anlamı”. Türklük Bilimi Araştırmaları 33 (2013): 61-92.

Çiğdem, Süleyman. Haldun Özkan. Hüseyin Yurttaş. Tarihi ve Kültürel Varlıklarıyla Bayburt. Bayburt: Bakütam Yayınları, 2020.

Çoruhlu, Yaşar. "Göktürk Sanatı”. Türkler Ansiklopedisi, c. 4. Ankara: Yeni Türkiye Yayınları, 2002, 148-161.

Çoruhlu, Yaşar. Erken Devir Türk Sanatı. İstanbul: Kabalcı Yayınevi, 2007.

Çoruhlu, Yaşar. Erken Devir Türk Sanatının ABC'si. İstanbul: Kabalcı Yayınevi, 1998.

Dağl1, Yücel. Seyit Ali Kahraman. Günümüz Türkçesiyle Evliya Çelebi Seyahatnamesi: Bursa-BoluTrabzon-Erzurum-Azerbaycan-Kafkasya-Kırım-Girit, 2. İstanbul: Yap1 Kredi Yayınlar1, 2008.

Denike, Boris. "Batı Türkistan'da Ahşap Oymalı Birkaç Abide.” Çev. Osman Uysal. Vakıflar Dergisi XX (1988): 29-38.

Eker, Süer. “Orta Asya’nın Gizemli Halk1: Soğdlular Soğd ve Soğdca”. Türkbilig 24, (2012):77-92.

Esin, Emel. "Türk Kubbesi, Gök-Türklerden Selçuklulara Kadar”. Selçuklu Araştırmaları Dergisi III, Malazgirt Zaferi Özel Sayısı. Ankara: Güven Matbaası, 1971, 159-182.

Eyice, Semavi. “Cami, Mimarlık Tarihi”. TDV İslam Ansiklopedisi, c. 7. İstanbul: Türkiye Diyanet Vakfi Yayınları, 1993, 59-62.

Hasol, Doğan. “Ahşap”. Eczacıbaşı Sanat Ansiklopedisi, c. 1. İstanbul: Yem Yayınevi, 1997, 33-34. İzgi, Özkan. Kutluk Bilge Kül Kağan- Böğ̈̈ Kağan ve Uygurlar. Ankara: Kültür ve Turizm Bakanlığ1 Yayınları, 1986.

Karamağral1, Haluk. "Erzurum Ulu Camii”. Yıllık Araştırmaları Dergisi III (1981): 137-178.

Karamağralı, Haluk. "Sâhib Atâ Câmii'nin Restitüyonu Hakkında Bir Deneme”. Rölöve ve Restorasyon Dergisi 3 (1985): 49-75.

Karpuz, Haşim. “İslam Öncesi Türk Sanatının İslami Döneme Etkisi”. Türkler Ansiklopedisi, c. 6. Ankara: Yeni Türkiye Yayınları, 2002, 46-53.

Konyalı, İbrahim Hakk1. Abideleri ve Kitabeleri ile Erzurum. İstanbul: Ercan Matbaası, 960.

Küçük, Ogün. “Trabzon'un Çaykara, Dernekpazarı, Hayrat ve Of İlçelerindeki Osmanlı Dönemine Ait Bazı Ahşap Camiler (18-19 yy)”. Yüksek Lisans Tezi, Yüzüncü Y1l Üniversitesi, 2017.

Merçil, Erdoğan. "Gazneliler”. TDV İslam Ansiklopedisi, c. 13. İstanbul: Türkiye Diyanet Vakfi Yayınlar1, 1996, 480-484. 
Narmanl1, Faruk. "Giresun Camilerinde Tezyinat”. Yüksek Lisans Tezi, Ondokuz Mayıs Üniversitesi, 2018.

Nefes, Eyüp. “Samsun'da Ahşap Bir Osmanlı Eseri Ayvacık/Tiryakioğlu Camii”. Ondokuz Mayıs Üniversitesi İlahiyat Fakültesi Dergisi 28 (2010), 151-174.

Osmanlı Ansiklopedisi, c.12. Ankara: Yeni Türkiye Yayınları, 1999, 17-21.

Ögel, Bahaddin. Türk Kültür Tarihi. Ankara: Türk Tarih Kurumu, 1984.

Önal, R. Çiğdem ve Zerrin Köşklü. "Trabzon'da Geç Dönem Osmanlı Camilerinde Ahşap Mihraplar". Sanat Tarihi Dergisi 29/2 (2020): 707-743.

Özbekistan Milli Ansiklopedisi, c. 1. Taşkent: Devlet Bilimsel Yayınevi, 2000.

Özdemir, Esin. “Ordu ve İlçelerindeki Türk Dönemi Mimari Eserleri”. Yüksek Lisans Tezi, Yüzüncü Y1l Üniversitesi, 2011.

Özkan, Haldun. Saltuklu Mimarisi. Erzurum: Zafer Medya Grup, 2016.

Özkan, Haldun. "Bayburt Dağçatı Köyü Camii ve Çeşmesi”. Güzel Sanatlar Enstitüsü Dergisi 31 (2013), 119-135.

Özkan, Haldun. "Bayburt Konursu Ulu Camii ve Çeşmesi”. Sanat Dergisi 13 (2008), 57-66.

Özkan, Haldun. Hüseyin Yurttaş. Ortaçağ'dan Günümüze Gümüşhane. Gümüşhane: Gümüşhane Valiliği Yayınları, 2012.

Parlak, Sevgi. "Sâhib Ata Külliyesi”. TDV İslam Ansiklopedisi, c. 35. İstanbul: Türkiye Diyanet Vakfi Yayınları, 2008, 516-518.

Rustamova, Muhlisahon. "Karahanlı Devri Mimarisi ve Bezemeleri”. Doktora Tezi, Marmara Üniversitesi, 2019.

Samsun Ahşap Camiler. Ed. Şenler Yıldız. Ankara: Sincan Matbaası, 2011.

Sarı, Yavuz. “Trabzon'un Hayrat, Of ve Sürmene İlçelerindeki Köy Camileri”. Yüksek Lisans Tezi, Ondokuz Mayıs Üniversitesi, 2016.

Sazak, Gözde. "Varahşa Sarayı Duvar Resimleri”. Tarih Dergisi 57 (2013): 1-23.

Sümer, Faruk. "Tuğrul Şah”. TDV İslam Ansiklopedisi, c. 41. İstanbul: Türkiye Diyanet Vakfı Yayınlar1, 2012, 346-347.

Sümer, Faruk. Eski Türklerde Şehircilik. İstanbul: Türk Dünyası Araştırmaları Vakfı Yayını, 1984.

Taşağıl, Ahmet. "Soğd”. TDV İslam Ansiklopedisi, c. 37. İstanbul: Türkiye Diyanet Vakfı Yayınları, 2009, 348-349.

Taşkan, Demet. “Artvin İli Borçka ve Hopa İlçeleri Camilerinde Ahşap Süsleme”. Yüksek Lisans Tezi, Gazi Üniversitesi, 2011.

Taşkan, Demet. “Trabzon İli Camilerinde Ahşap Minberler”. Doktora Tezi, Gazi Üniversitesi, 2016.

Yaman, Bahattin. "XIII. yüzyıl Anadolu Taçkapıları'nda Kullanılan Madalyon ve Kabaralar”. İstem 33 (2019), 127-147.

Yaşayacak, İlyas. “Afyonkarahisar'daki Ahşap Destekli Camiler”. Yüksek Lisans Tezi, Ege Üniversitesi, 2018.

Yavaş, Doğan. "Eşrefoğlu Camii”. TDV İslam Ansiklopedisi, c. 11. İstanbul: Türkiye Diyanet Vakfı Yayınlar1, 1995, 479-480.

Youngs, Robert L. "History, Nature and Products of Wood". Forests And Forest Plants, Vol. II, United Kingdom: EOLSS Publications, 2009, 131-140. 
Yurttaş, Hüseyin, Haldun Özkan, Zerrin Köşklü, Şerife Tali, Demet Okuyucu, Gül Geyik ve Muhammed Kındığılı. Yolların, Suların ve Sanatın Buluştuğu Şehir Erzurum. Ankara: Kariyer Matbaacilik, 2008.

Ziyai, Alimcan. “Orijinal Çin Kaynaklarına Göre Hun-Türk Tarihi I. Bölüm: Kudretli Büyük Hun Tanrıkutluğu (Türk Halkının Ataları Hunlar ve Hunların Ortaya Çıkış1)”. Gazi Üniversitesi Eğitim Fakültesi Dergisi 30 (3), (2010), 895-912.

Erişim 05 Şubat 2021. http://www.iranicaonline.org/articles/bestam-3\#prettyPhoto[content]/0/

Erişim 1 Haziran 2021. https://karadeniz.gov.tr/

Erişim 15 Haziran 2021. https://karadeniz.gov.tr/bulanik-koyu-camii/

Erişim 15 Ocak 2021. https://karadeniz.gov.tr/kulturel-varliklar-2/?vilayet=5\&kaza=0\&tip=5\&ar $\mathrm{ama}=$

Erişim 15 Ocak 2021. https://karadeniz.gov.tr/zahit-efendi-camii/

Erişim 16 Ocak 2021. https://karadeniz.gov.tr/muratli-camii/\#prettyPhoto

Erişim 17 Nisan 2021. https://www.indigenousoutsiders.com/akho

Erişim 15 Ocak 2021. https://karadeniz.gov.tr/kulturel-varliklar-2/?vilayet=2\&kaza=0\&tip=5\&ara ma $=$ camii\&sahife $=3$

Erişim 27 Temmuz 2021. https://kuran.diyanet.gov.tr/tefsir/\%C3\%821-i\%20\%C4\%B0mr\%C3\%A2nsuresi/330/37-ayet-tefsiri 


\section{EKLER}

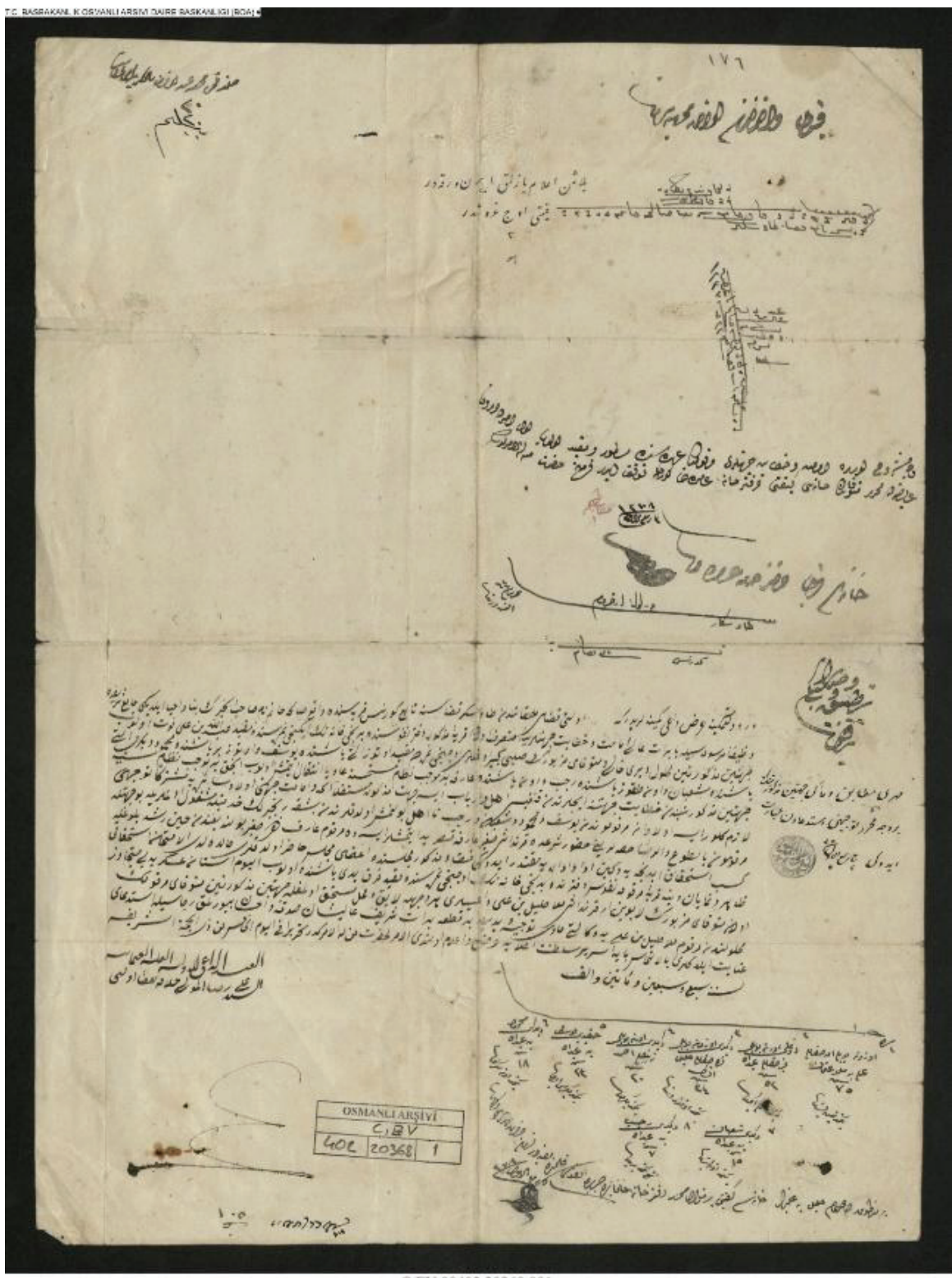

C.EV.00402.20368.001

Ek 1: BOA, C.EV. 00402.20368.001 


\section{BOA, C_EV_00402_20368_002_001}

Mübârek makâm-ı mu'allâ-yı cenâb-ı nezâret-i celîle-i evkâf-ı hümâyûn

Çıldır sancă̆ı dâhilinde kâin Tavusger kazâsında vâkl' Görnes nâm karye sâkinlerinden merhûmetü'l-mağfûre Saliha Hanım 'ın binâ ve hayrât eylemiş olduğu câmi '-i şerîfin imâmet ve hitâbet cihetlerine vazîfe-i mersûme ile bâ berât-l âlî mutasarrıfi bulunan Abdullah bin Ali fevt olarak sulb-i sahîh-i kebîr oğulları Yusuf ve Mahmud ve Recep ile sabî oğulları Şaban ve Arif'i terk ederek ciheteyn-i mezkûreteynden hitâbet cihetinin müstakullen birine ve imâmet cihetinin dahi müsstereken diğerlerine tevcîhi müesses olan nizâm-ı âlî iktizâsından olup fakat müteveffâ-yı merkûmun kebîr oğullarından Yusuf ve Şaban ve Mahmud ve Recep nâ-ehil olarak ciheteyn-i mezkûrteyni hüsn-i îfâya adîmü'l-iktidâr olduklarından hisselerini huzûr-ı şer 'îde karındaşları sagîr Arif'e kasr-ı yed eylemiş iseler de merkûm dahi sabî olduğundan hîn-i rüşd ve bulûğuna değin bi 'l-vekâle idâre etmek üzre bi 'l-imtihân ehliyeti zâhir ve nümâyân olan karye-i mezbûrun yedinci hânesinin üçüncü numara ve kırk yedi yaşında mukayyed bulunarak esnân-ı askeriyeyi tecâvüz etmiş olan müteveffâyı mûmâ ileyhin karındaşı Molla Halil bin Ali dâ îlerine ciheteyn-i mezkûrteynin tevcîhiyle berât-ı şerîf-i âlî̧̧ânın sadaka ve i 'tâsı ma 'razında kıbel-i şer 'îden tanzîm olunan i 'lâm manzûr-ı me âlî-nüşûr-ı nezâret-penâhîleri buyrulmak üzre leffen takdîm olunmuş ve ol vechile iktizâ-yı hâlin icrâsıyla ciheteyn-i mezkûrteynin mûmâ ileyh Molla Halil bin Ali dâ îlerine tevcîhiyle berât-l şerîf-i âlîş̧anıı ihsân ve isrâsı mahzâ müsâ 'ade-i ihsân-âde-i hazret-i nezâret-penâhîlerine menût bulunmuş olmağla ol bâbda ve her hâlde emr ü fermân hazret-i menlehü'l-emrindir.

Fî 15 Muharrem sene 1278

Bende kâimmakâm-ı liva-i Çıldır es-Seyyid Abdurrahman Ziya

Ed-Dầînâib-i Otis es-Seyyid Ali Rıza

Ed-Dâ '̂̀ kâdî-i Otis Abdullah Osman

Bende an Serbevvâbîn İsmail Torun

Bende Serkâtib-i Mâl es-Seyyid Mehmed Ragıb

Bende Kâtib-i tahrîrât Mehmed Halid

Bende Nâzır-ı nüfûs a 'zâ es-Seyyid Mehmed Kemaleddin

Bende a'zâ / Bende a'zâ es-Seyyid İsmail / Bende a'zâ Yusuf Ziya / Bende a'zâ (mühür) / Bende a 'zâ Halil Rüşdü / Bende emîn-i sandık Hasan Himmet 


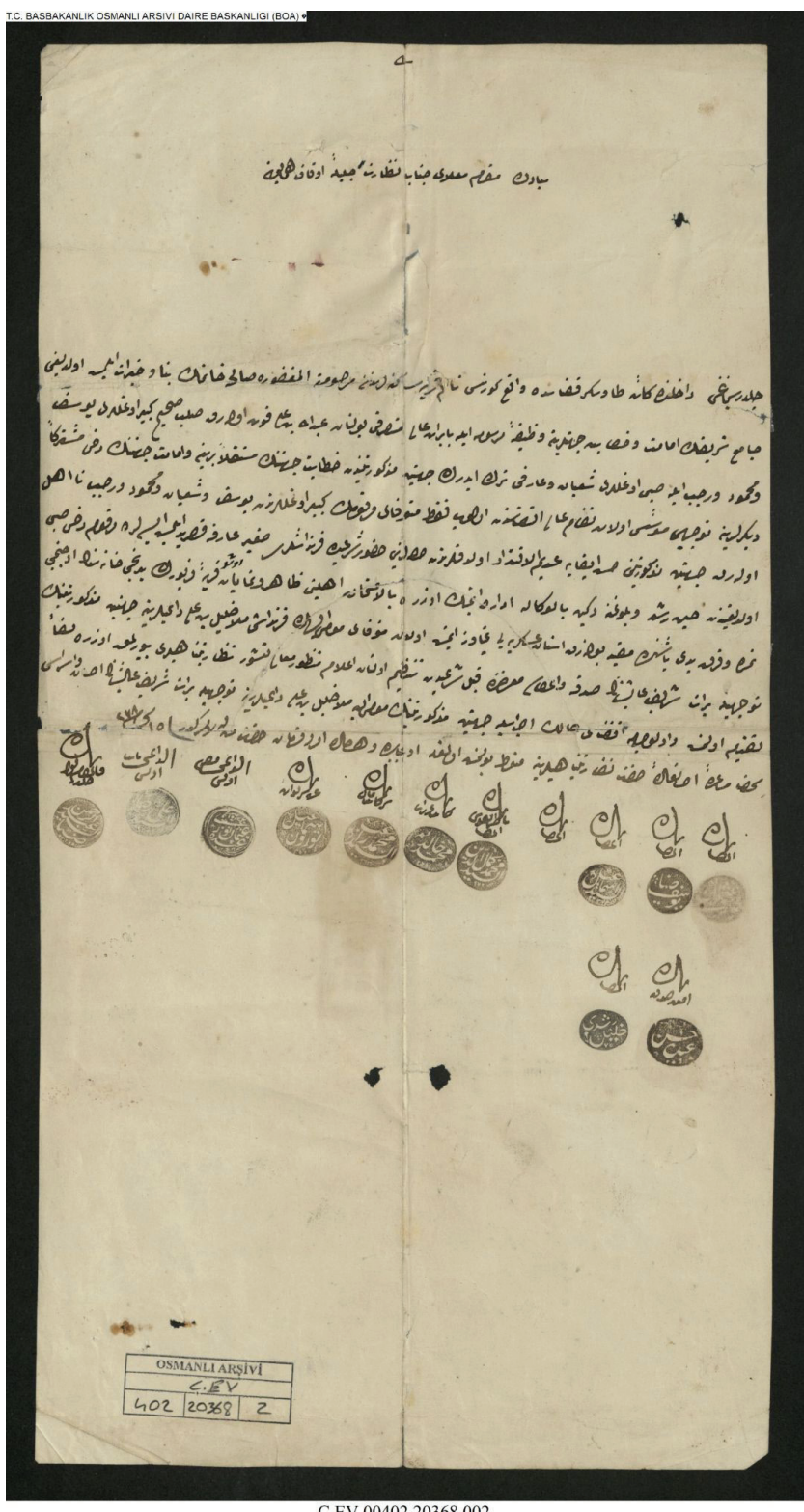

C.EV.00402.20368.002

Ek 2: BOA, C.EV.00402.20368.002 


\section{BOA, C_EV_00402_20368_001_002}

Meâl-i i 'lâm ve merbût mazbata derkenârda muharrer imâmet ve hitâbet cihetlerine mutasarrlf olan Abdullah bin Ali'nin fevtiyle mahlûlünden ve sulbî kebîr oğulları Yusuf ve Mahmud ve Şaban ve Receb'in nâ-ehl oldukları beyânıla kasr-l yedlerinden diğer sulbî sagîr oğlu Arif'in rüşd-i bulûğ ve kesb-i istihkâkına değin tarafindan lede'l-imtihân istihkâkı zâhir ve nümâyân ve esnân-l askeriyeyi mütecâviz olan müteveffâ-yı merkûmun li ebeveyn karındaşı Molla Halil bin Ali bi'n-niyâbe edâyı hıdmet etmek üzre sagîr-i merkûma tevcîhine dâir olup ve ciheteyn-i mezkûrteyn derkenârda gösterildiği vechile müteveffâ-yı merkûmun elyevm uhdesinde mukayyed olarak ber mantûk-ı arîza Yusuf ve Mahmud ve Şaban ve Receb isimlerinde dört nefer oğullarl olduğu defterhâne-i âmireden bi'l-ihrâc sagîr-i merkûm Arif'in tevellüdine dâir kayd bulunmadı̆̆ının cevâbı tahrîr olunmuş ise de meâl-i arîza berât kaydına ve nizâmına muvâfik bulunmuş olmă̆la bu sûretde ciheteyn-i mezkûrteyn inhâ olunduğu vechile mutasarrıfı müteveffâ-yı merkûmun mahlûlünden ve sulbî kebîre oğulları Yusuf ve Mahmud ve Şaban ve Receb'in kasr-l yedlerinden diğer sulbî sagîr oğlu merkûm Arif'in edâ-yı hıdmete kesb-i istihkâkına değin tarafindan mûmâ ileyh Melek Halil bin Ali bi'n-niyâbe edâ-yı hıdmet etmek üzre sagîr-i merkûm Arif'e müstakıllen tevcîhiyle bâ ruus-ı hümâyûn berât $i$ 'tâsı cânib-i nezâret-penâhîlerinden bâ i 'lâm ancak hitâbeti hatt-ı hümâyûn-ı şevket-makrûn-l cenâb-ı mülûkâne şeref-sunûh ve sudûr buyrulmağa tevakkuf eder fermân hazret-i menlehü'l-emrindir.

Fî 17 Râ sene 1278

I'lâm

Telhîs fî gurre-i Cemâziye'l-evvel sene 78

Zihni Efendi'nin

Sandıkçı Mehmed

Ber mûceb-i i 'lâm tevcîh berâtı i 'tâ olunmak buyruldu.

Fî 4 Rebiülahir sene 278

Ma'rûz-ı çâker-i kemîneleridir ki

İşbu i 'lâm ve merbût mazbata ve derkenârlarda gösterildiği vechile Erzurum sancă̆ında Tavusger kazâsına tâbi ' Görnes karyesinde vâkı 'Saliha Hanım 'ın câmi '-i şerîfi vakfinın vazîfe-i mu'ayyene ile imâmet ve hitâbet cihetleri mutasarrıfi Abdullah Efendi ile Ali'nin vefâtı vukû 'ryla mahlûlünden ve beş nefer sulbî kebîr oğullarindan Yusuf ve Mahmud ve Şaban ve Receb'in adem-i ehliyetleri cihetiyle kasr-l yedlerinden diğer sulbî sagîr oğlu Arif'in bâliğ olup bi'n-nefs edâ-yı hıdmete kesb-i istihkâkına değin tarafindan bi'l-imtihân istihkâkı olup esnân-ı askeriyeyi mütecâviz olan müteveffânın li-ebeveyn karındaşı Molla Halil Efendi ibni Ali bi'n-niyâbe edâ-yı hıdmet etmek üzre sagîr-i mûmâ ileyh Arif Efendi'ye müstakıllen tevcîhi îcâbından ve fakat hitâbet husûsu hatt-ı hümâŷ̂n-ı meyâmin-makrûn-ı cenâb-l şâhâneye mütevak- 
klf mevâddan olmağla ol vechile bi 't-tevcîh şurûtı derciyle kaleminden iktizâ eden berât-ı şerîfin i'tâsiyçün ruus-ı hümâyûnun takdîri bâbında emr ü fermân hazret-i veliyyü'l-emrindir.

Fî 26 Rebiülevvel sene 278

Şeyh Abdüllatif 


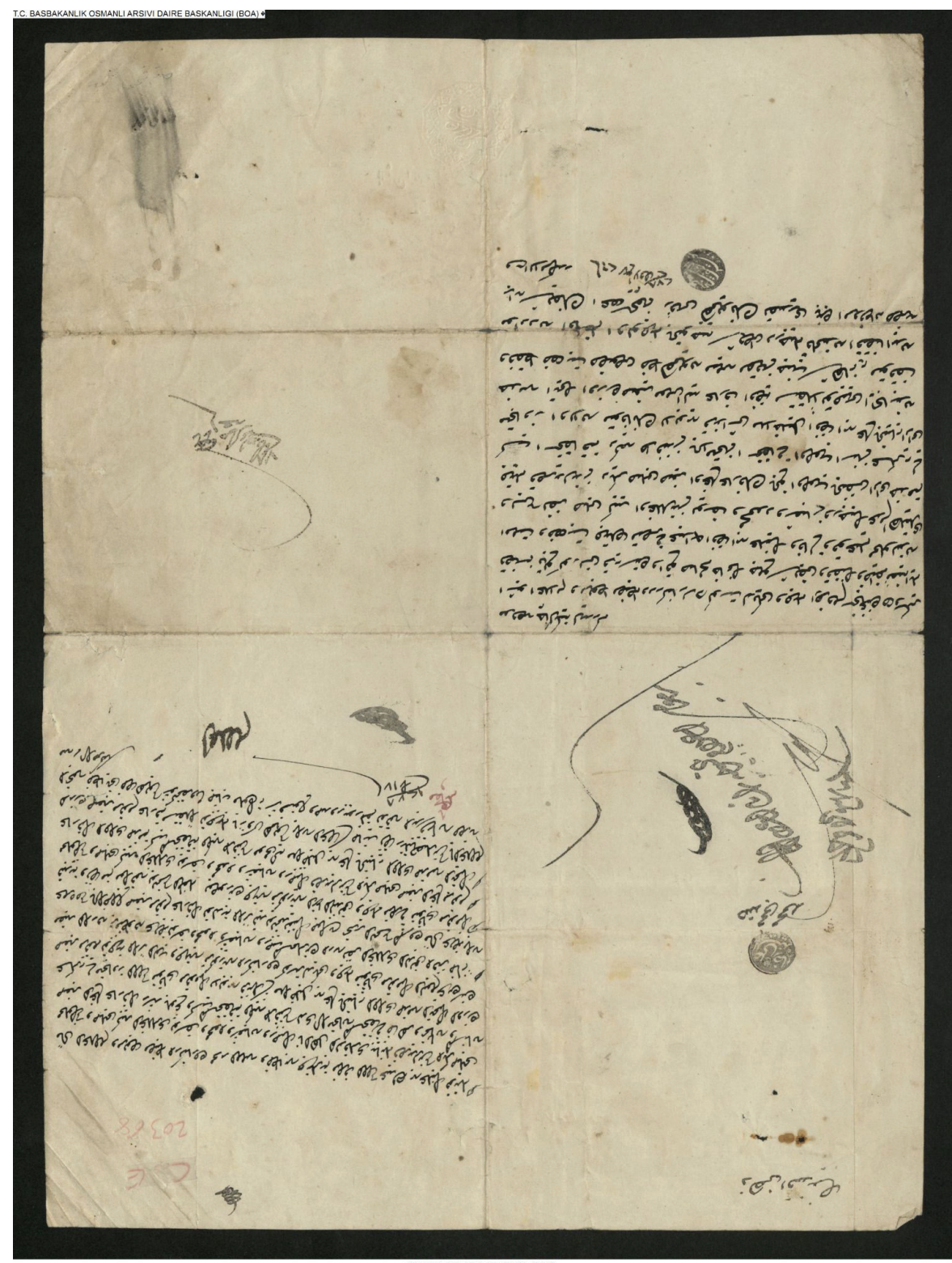

C.EV.00402.20368.001

Ek 3: BOA, C.EV.00402.20368.001 


\section{BOA, C_EV__00402_20368_001_001}

Bilâ semen i 'lâm yazılmak içün varakadır

Klymeti üç guruşdur

Kaydı ve iktizâsı üzre muhâsebesinden.

Defter-i evkâf-ı câmi 'i ş̧erîf Saliha Hanım der karye-i Görnes tâbi '-i kazâa-i Tavusger

Ali bin Abdullah kassâm-ı vakf-ı şerîf

Vech-i meşrûh üzre imâmet ve hitâbet cihetleri merkûmun uhdesinde mestûr ve mukayyed olup evvel emirde derûn-ı arîzada muharrer müteveffânın hânesi keyfiyeti defterhâne-i âmireden görülmeğle tevakkuf eder fermân hazret-i menlehü'l-emrindir.

Fî 3 Rebiülevvel sene 1278

Hânesi kaydı defterhâne-i âmireden

Kazâ-i Tavusger der livâ-i Erzurum / tahrîr sene 64 altmış dörtdür.

Karye-i Görnes tâbi 'i kazâ-i mezbûr

Tatbîk ve vaz'ının sebki terkîn.

Mührü mutâbık ve meâli ciheteyn-i mezkûrteynin ber vech-i muharrer tevcîhini istid 'âdan ibâret idüği.

Fî 2 Rebiülevvel sene 78

Mühür: Emînü'l-Fetvâ

Hâne 1

\begin{tabular}{|c|c|c|c|}
\hline $\begin{array}{l}\text { Numara } 1 \\
\text { Orta boylu ak sakallı Ali } \\
\text { bin Molla Osman } \\
\text { Sinn } 75 \text { / yalnız yetmiş } \\
\text { beşdir }\end{array}$ & $\begin{array}{l}\text { Numara } 2 \\
\text { Ŏglu orta boylu kır } \\
\text { sakallı Abdullah } \\
\text { Sinn } 52 \text { / yalnız elli } \\
\text { ikidir }\end{array}$ & $\begin{array}{l}\text { Numara } 3 \\
\text { Diğeri uzun boylu kara } \\
\text { sakallı Halil Efendi } \\
\text { Sinn } 34 \text { / yalnız otuz } \\
\text { dörtdür }\end{array}$ & $\begin{array}{l}\text { Numara } 4 \\
\text { Diğeri orta boylu ter } \\
\text { bıyıklı Ahmed } \\
\text { Sinn } 20 \text { / yalnı yirmidir }\end{array}$ \\
\hline $\begin{array}{l}\text { Numara } 5 \\
\text { Hafídi Yusuf bin Abdullah } \\
\text { Sinn } 23 \text { / yalnız yirmi } \\
\text { üçdür }\end{array}$ & $\begin{array}{l}\text { Numara } 6 \\
\text { Diğeri Mahmud bin } \\
\text { Abdullah } \\
\text { Sinn } 18 \text { / yalnız on } \\
\text { sekizdir }\end{array}$ & $\begin{array}{l}\text { Numara } 7 \\
\text { Diğeri Şaban bin Abdul- } \\
\text { lah } \\
\text { Sinn } 15 \text { / yalnız on beşdir }\end{array}$ & $\begin{array}{l}\text { Numara } 8 \\
\text { Diğeri Receb bin Abdul- } \\
\text { lah } \\
\text { Sinn } 7 \text { yalnız yedidir }\end{array}$ \\
\hline
\end{tabular}

Ber mantûk-ı i'lâm Halil bin Ali'nin hânesi keyfiyeti ber minvâl-i muharrer defterhâne-i hâkânîde cerîde-i nüfûs kaleminde mukayyeddir fermân hazret-i menlehü'l-emrindir. 
Fî 5 Rebiülevvel sene 278

Der-devlet-mekîne-i arz-ı dâ 'î-i kemîneleridir ki Oltu kazâsı mülhakâtından Tavusger kazâsına tâbi ' Görnes karyesinde vâkı 'Saliha Hânım nâm sâhibü'l-hayrın binâ ve ihyâ eylediği câmi'-i şerîfde vazîfe-i mersûmesiyle bâ berât-l âli imâmet ve hitâbet cihetlerine mutasarrı olan karye-i mezkûre defter-i nüfûsunda birinci hânenin ikinci numarasinda mukayyed Abdullah bin Ali fevt olup ciheteyn-i mezkûrteyn mahlûl ve yeri hâlî ve müteveffâ-yı mezbûrun sulbî kebîr oğulları üçüncü numarada mukayyed otuz altı yaşında Yusuf ve otuz bir yaşında Mahmud ve diğeri altı yaşında Şaban ve on dokuz yaşında Recep ve on yaşında Arif'e ber mûceb-i nizâm-ı müstahsene âdiyen intikâl etmiş olup ancak ber mûceb-i nizâm-l seniyye ciheteyn-i mezkûrteynden hitâbet cihetine içlerinden kangısı ehil ve erbâb ise cihet-i mezkûre müstakıllen âna ve imâmet ciheti evlâd-ı sâirine müştereken tevcîhi lâzım gelir ise evlâdân-ı merkûmûndan Yusuf ve Mahmud ve Şaban ve Recep nâ-ehil bulunmuş olduklarından başka rençberlik hıdmetiyle meşgûl olmalarıla bu cihetle merkûmûn bi 't-tav've'r-rızâ hisselerini huzûr-l şer 'de karındaşı sagîr Arif'e kasr-l yed etmişler ise de merkûm Arif dahi sagîr bulunduğundan hîn-i rüşd-i bulûğuyla kesb-i istihkâk edinceye değin edâ ve idâreye muktedir idüği kazâ-i mezkûr meclisinde a 'zâ-yı meclis hâzır oldukları halde lede'limtihân istihkâkı zâhir ve nümâyân ve yine karye-i merkûme nüfûs defterinde yedinci hânenin üçüncü numarasında mukayyed kırk yedi yaşında olup elyevm esnân-ı askeriyeyi mütecâviz olan müteveffâ-yı mezbûrun li-ebeveyn er karındaşı Molla Halil bin Ali dâ 'îleri her vechile lâyık ve mahall ve müstehakk olmağla ciheteyn-i mezkûrteyn müteveffâ-yı merkûmun mahlûlünden merkûm Molla Halil bin Ali'ye vekâleti hâvî tevcîh ve yedine bir kut'a berât-l şerîf-i âlîşân sadaka ve ihsân buyrulmak ricâsıyla istid' $\hat{a}-y$ in $\hat{y}$ yet eyledikleri bi'l-iltimâs pâye-i serir-i saltanat-l a 'lâya arz ve i 'lâm olundu el-emr li-hazret-i menlehü'l-emrindir tahrîren fi'l-yevmi'l-hâmis min Zi'lhicceti'ş-şerîfe lisene seb'a ve seb 'în ve mieteyn ve elf

El-abdü'd-dâ '̂̀ li'd-devleti'l-aliyyeti'l-Osmâniye es-Seyyid Ali Rıza el-müvellâ hilâfehu be-kazâ-i Oltu 
